ARTICLE

https://doi.org/10.1038/s41467-019-14153-7

\title{
Alloying design of biodegradable zinc as promising bone implants for load-bearing applications
}

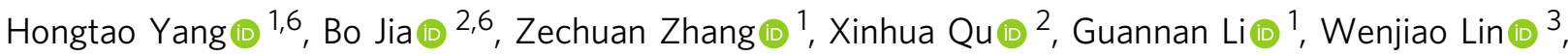 \\ Donghui Zhu (i] ${ }^{4}$, Kerong Dai (10) ${ }^{2 \star} \&$ Yufeng Zheng (i) ${ }^{1,5 *}$
}

Magnesium-based biodegradable metals (BMs) as bone implants have better mechanical properties than biodegradable polymers, yet their strength is roughly less than $350 \mathrm{MPa}$. In this work, binary $\mathrm{Zn}$ alloys with alloying elements $\mathrm{Mg}, \mathrm{Ca}, \mathrm{Sr}, \mathrm{Li}, \mathrm{Mn}, \mathrm{Fe}, \mathrm{Cu}$, and $\mathrm{Ag}$ respectively, are screened systemically by in vitro and in vivo studies. Li exhibits the most effective strengthening role in $\mathrm{Zn}$, followed by $\mathrm{Mg}$. Alloying leads to accelerated degradation, but adequate mechanical integrity can be expected for $\mathrm{Zn}$ alloys when considering bone fracture healing. Adding elements $\mathrm{Mg}, \mathrm{Ca}, \mathrm{Sr}$ and $\mathrm{Li}$ into $\mathrm{Zn}$ can improve the cytocompatibility, osteogenesis, and osseointegration. Further optimization of the ternary $\mathrm{Zn}-\mathrm{Li}$ alloy system results in $\mathrm{Zn}-0.8 \mathrm{Li}-0.4 \mathrm{Mg}$ alloy with the ultimate tensile strength $646.69 \pm 12.79 \mathrm{MPa}$ and $\mathrm{Zn}-0.8 \mathrm{Li}-0.8 \mathrm{Mn}$ alloy with elongation $103.27 \pm 20 \%$. In summary, biocompatible $\mathrm{Zn}$ based BMs with strength close to pure Ti are promising candidates in orthopedics for loadbearing applications.

\footnotetext{
${ }^{1}$ Beijing Advanced Innovation Center for Materials Genome Engineering \& Department of Materials Science and Engineering, College of Engineering, Peking University, Beijing 100871, China. ${ }^{2}$ Department of orthopaedic surgery, Shanghai Key Laboratory of Orthopedic Implants, Shanghai Ninth People's Hospital, Shanghai Jiaotong University School of Medicine, Shanghai 200011, China. ${ }^{3}$ R\&D Center, Lifetech Scientific (Shenzhen) Co Ltd, Shenzhen 518057, China. ${ }^{4}$ Department of Biomedical Engineering, College of Engineering and Applied Sciences, Stony Brook University, Stony Brook, NY 11794-5281, USA.

${ }^{5}$ International Research Organization for Advanced Science and Technology, Kumamoto University, 2-39-1 Kurokami, Chuo-Ku, Kumamoto 860-8555, Japan. ${ }^{6}$ These authors contributed equally: Hongtao Yang, Bo Jia. *email: krdai@163.com; yfzheng@pku.edu.cn
} 
$\mathrm{T}$ o address the clinical problems associated with stress shielding and secondary surgery, biodegradable materials provide an alternative option to permanent materials in orthopedics. Biodegradable polymers like poly(glycolic acid) (PGA), poly(L-lactic acid) (PLLA) and poly(lactic acid-co-glycolic acid) (PLGA) have been approved by Food and Drug Administration (FDA) for clinical use as bone screws, nails and pins, suture anchors and meniscal darts, etc ${ }^{1,2}$. Meanwhile, bone screws made of $\mathrm{Mg}-\mathrm{Y}-\mathrm{RE}-\mathrm{Zr}^{3}$ and $\mathrm{Mg}-\mathrm{Ca}-\mathrm{Zn}^{4}$ alloys have been approved by Conformité Européene (CE) and the Korea Food and Drug Administration (KFDA) in 2013 and 2015, respectively. Additionally, high purity $\mathrm{Mg}$ screws used for fixation of autologous bone grafts or bone fractures are undergoing clinical trials in China ${ }^{5}$. However, there is still a great gap between the mechanical strength of biodegradable materials like polymers ${ }^{1,2}$ and $\mathrm{Mg}$ alloys ${ }^{6}$ (UTS $<350 \mathrm{MPa}$ ) and traditional metallic materials like cobalt chromium alloys ${ }^{7}, 316 \mathrm{~L}$ stainless steel and titanium-based alloys ${ }^{8}$ (UTS $>500 \mathrm{MPa}$ ). Therefore, the clinical use of biodegradable implants has been limited to non or low load-bearing applications such as fixation of small bone and cancellous fragments, meniscus repair and soft tissue fixation ${ }^{2-4}$.

Recent advances in biodegradable $\mathrm{Zn}$ alloys have developed novel alloy systems such as $\mathrm{Zn}-\mathrm{Mg}^{9,10}$ (UTS 155-455 MPa) and Zn-Li1 ${ }^{11}$ (UTS 360-560 MPa) alloys with outstanding mechanical strength. Zinc plays an essential role in bone metabolism. Zinc supplementation stimulates osteoblast bone formation, meanwhile, inhibiting osteoclast differentiation and results in increased bone strength ${ }^{12,13}$. Therefore, biodegradable $\mathrm{Zn}$ alloys appear to exhibit distinct advantages over biodegradable polymers and Mg alloys in orthopedic applications. However, current research of biodegradable $\mathrm{Zn}$ alloys has focused on material aspects. A wide range of composition has been explored without a clear design principle ${ }^{14,15}$. For bone implants, limited publications have focused on only three alloy systems including $\mathrm{Zn}-\mathrm{Mg}, \mathrm{Zn}-\mathrm{Ca}$, and $\mathrm{Zn}-\mathrm{Sr}$ alloys ${ }^{9,16-19}$. Moreover, in vitro methodology has been performed predominantly in these studies. According to the research experience from biodegradable $\mathrm{Mg}$ alloys ${ }^{20}$, the existence of a great discrepancy between in vitro and in vivo data makes it hard to predict the real performance of implants under physiological conditions. Therefore, it is necessary to combine the findings from both in vitro and in vivo to instruct the alloying design for $\mathrm{Zn}$ alloys as bone implants. To establish binary $\mathrm{Zn}$ alloy systems, eight beneficial elements for bone health including $\mathrm{Mg}^{21}, \mathrm{Ca}^{22}, \mathrm{Sr}^{23,24}, \mathrm{Li}^{25,26}, \mathrm{Mn}^{27}$, $\mathrm{Fe}^{28,29}, \mathrm{Cu}^{30,31}$, and $\mathrm{Ag}^{32}$ were selected as alloying elements adding into zinc. For elements with low or no solubility in zinc ( $\mathrm{Mg}, \mathrm{Ca}, \mathrm{Sr}, \mathrm{Li}, \mathrm{Mn}$, and $\mathrm{Fe}$ ), alloy contents were set at $0.1,0.4$, and $0.8 \mathrm{wt} \%$. $\mathrm{Cu}$ and $\mathrm{Ag}$ were added at $0.4,0.8$, and $2.0 \mathrm{wt} \%$ due to their relatively high solubility in zinc.

In this study, binary $\mathrm{Zn}$ alloys were screened by in vitro tests in the context of mechanical property, corrosion behavior, and cellular response. Alloy composition with superior performance in each alloy system was further implanted into rat femur for in vivo evaluation. Ternary $\mathrm{Zn}-\mathrm{Li}-\mathrm{X}(\mathrm{X}=\mathrm{Mg}$ or $\mathrm{Mn})$ alloys were designed as an optimization based on the $\mathrm{Zn}-\mathrm{Li}$ alloy system. As a result, the alloying design strategy for $\mathrm{Zn}$ alloys as bone implants is proposed regarding the mechanical property, biodegradation, and biocompatibility. The present study may provide guidance on the future clinical prospects of $\mathrm{Zn}$-based materials in orthopedic applications.

\section{Results}

Microstructure analysis. Supplementary Fig. 1 and Fig. 1a presents SEM micrographs showing the microstructure of asextruded pure $\mathrm{Zn}$ and binary $\mathrm{Zn}$ alloys at different alloy contents. The microstructure of pure $\mathrm{Zn}$ was refined after extrusion with a grain size of less than $10 \mu \mathrm{m}$. Distinct features were observed in different alloy systems compared with pure $\mathrm{Zn}$. At low alloy contents (Supplementary Fig. 1), although X-ray diffraction only identified the intermetallic phases in $\mathrm{Zn}-0.1 \mathrm{Li}$ and $\mathrm{Zn}-0.1 \mathrm{Ca}$ alloys, intermetallic phases could be observed in $\mathrm{Zn}-0.1 \mathrm{Mg}, \mathrm{Zn}-0.1 \mathrm{Sr}$, and $\mathrm{Zn}-0.1 \mathrm{Fe}$ alloys as well due to their limited or no solubility in $\mathrm{Zn}$ (Mg: $0.1 \mathrm{wt} \%$ at $364^{\circ} \mathrm{C}$, Sr and Fe: no solubility in $\mathrm{Zn}$ ). In contrast, $\mathrm{Zn}-0.1 \mathrm{Mn}, \mathrm{Zn}-0.4 \mathrm{Cu}$, and $\mathrm{Zn}-0.4 \mathrm{Ag}$ alloys consisted of single-phase solid solutions as a result of their relatively high solubility in $\mathrm{Zn}(\mathrm{Mg}: \sim 0.8 \mathrm{wt} \%$ at $405^{\circ} \mathrm{C}$, Cu: $2.75 \mathrm{wt} \%$ at $425^{\circ} \mathrm{C}, \mathrm{Ag}: 8 \mathrm{wt} \%$ at $431^{\circ} \mathrm{C}$ ). At high alloy contents (Fig. 1), the volume fraction of intermetallic phases increased in all alloy systems. The feature of intermetallic phases in different alloy systems could be roughly divided into two categories. The first category is the case where the size of the second phase was larger than the grain size of surrounding $\mathrm{Zn}$-rich matrix, such as in $\mathrm{Zn}-2.0 \mathrm{Cu}, \mathrm{Zn}-0.8 \mathrm{Ca}, \mathrm{Zn}-0.8 \mathrm{Fe}$, and $\mathrm{Zn}-0.8 \mathrm{Sr}$. The second is the opposite case where the size of the second phase was finer than the $\mathrm{Zn}$ grain, such as in $\mathrm{Zn}-2.0 \mathrm{Ag}$, $\mathrm{Zn}-0.8 \mathrm{Mg}, \mathrm{Zn}-0.8 \mathrm{Li}$, and $\mathrm{Zn}-0.8 \mathrm{Mn}$. X-ray diffraction identified the characteristic peaks of intermetallic phases formed between $\mathrm{Zn}$ and alloying elements (Fig. 1b). Generally, biphasic microstructures were typical in binary $\mathrm{Zn}$ alloy systems with relatively high alloy contents. Quantitively analysis illustrated that the intermetallic phases in $\mathrm{Zn}-2.0 \mathrm{Ag}\left(\mathrm{AgZn}_{3}\right), \mathrm{Zn}-2.0 \mathrm{Cu}\left(\mathrm{CuZn}_{5}\right)$, and $\mathrm{Zn}-0.8 \mathrm{Mg}\left(\mathrm{Mg}_{2} \mathrm{Zn}_{11}\right)$ contained relatively higher contents of alloying elements than other groups (Fig. 1c).

Mechanical performance. The mechanical properties were evaluated by tensile test, compression test, and microhardness. As shown in Fig. 2a, dramatic differences were found in tensile strength and elongation when adding different elements even at minor additions. Among them, $\mathrm{Li}, \mathrm{Mg}, \mathrm{Cu}, \mathrm{Ag}$, and $\mathrm{Mn}$ demonstrated strengthening effects on pure $\mathrm{Zn}$. Moreover, the strength is further improved with element contents. Li played the most significant role in strengthening the $\mathrm{Zn}$ matrix. Addition of $0.1 \mathrm{wt} \% \mathrm{Li}$ increased the ultimate tensile strength (UTS) of pure $\mathrm{Zn}$ from $166.79 \pm 6.36 \mathrm{MPa}$ to $431.27 \pm 5.89 \mathrm{MPa} \quad(n=3)$. $\mathrm{Zn}-0.4 \mathrm{Li}$ alloy reached the maximum UTS of $520.36 \pm 1.83 \mathrm{MPa}$ $(n=3)$. We failed to record the strength of the $\mathrm{Zn}-0.8 \mathrm{Li}$ alloy because it fractured before yielding. However, the ductility declined significantly with $\mathrm{Li}$ and $\mathrm{Mg}$ additions. $\mathrm{Zn}-\mathrm{Cu}, \mathrm{Zn}-\mathrm{Ag}$, and $\mathrm{Zn}-\mathrm{Mn}$ alloys maintained superior ductility compared with pure $\mathrm{Zn}$. What stands out is that the addition of $0.8 \mathrm{wt} \% \mathrm{Ag}$ and $\mathrm{Mn}$ even improved the elongation to failure of pure $\mathrm{Zn}$ from $39.22 \pm 2 \%$ to $58.22 \pm 7.18 \%$ and $83.96 \pm 2.36 \%(n=3)$, respectively. In contrast, alloying with $\mathrm{Ca}, \mathrm{Fe}$, and $\mathrm{Sr}$ up to $0.8 \mathrm{wt} \%$ appeared to have little influence on the strength of pure $\mathrm{Zn}$. Additionally, their ductility dropped with contents. The influence of alloying elements on compressive strength (Fig. 2b) and microhardness (Fig. 2c) was similar to that on tensile strength. Surprisingly, adding Ag caused a decrease in compressive strength indicating an opposite role of $\mathrm{Ag}$ in tensile and compressive behavior of $\mathrm{Zn}$.

Corrosion behavior. Immersion test and electrochemical test were utilized to assess the corrosion behavior of binary $\mathrm{Zn}$ alloys with pure $\mathrm{Zn}$ as control. Supplementary Fig. 2 provides the representative corrosion morphologies of samples after immersion in SBF for 30 days. Pure $\mathrm{Zn}$ was covered by an intact corrosion layer with tiny precipitates on the surface. This layer was relatively thin with the scratches left by grinding could be clearly seen. In contrast, the corrosion morphologies of binary $\mathrm{Zn}$ alloys were similar to that of pure $\mathrm{Zn}$ except $\mathrm{Zn}-0.8 \mathrm{Ca}$ alloy. A thicker 

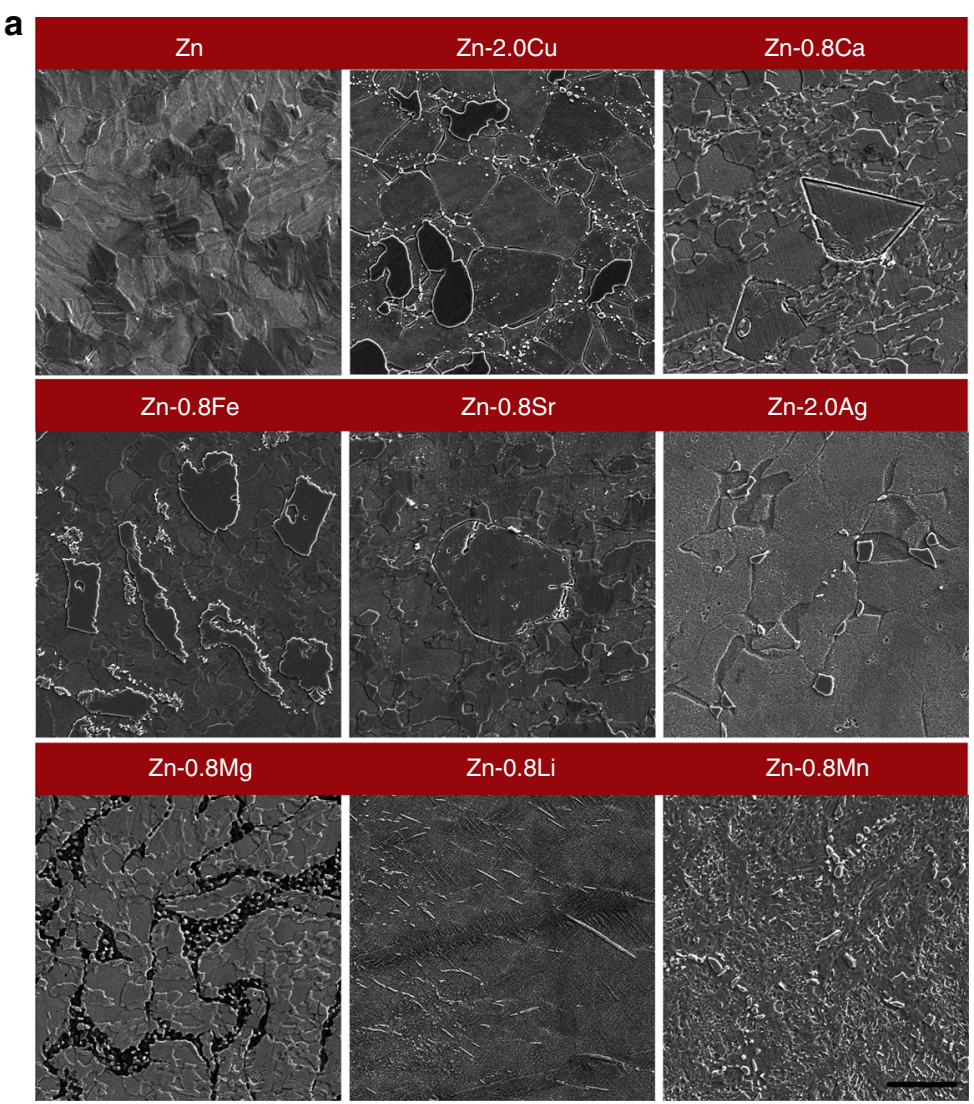
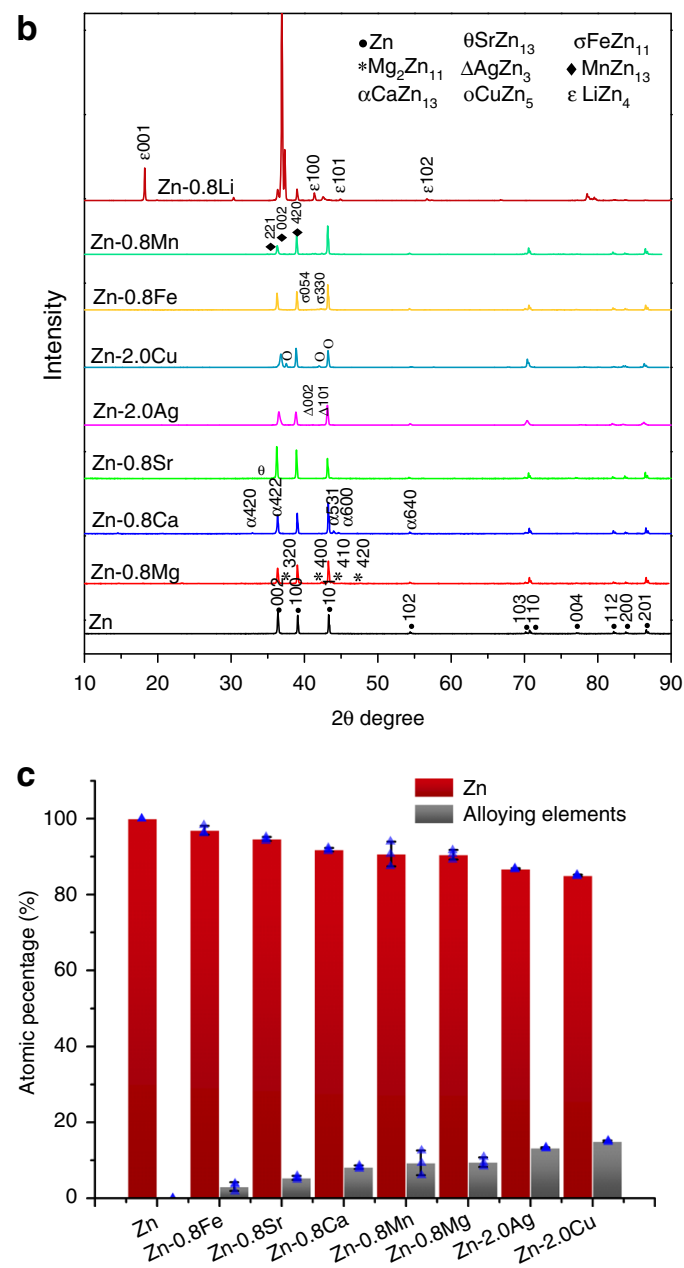

Fig. 1 Microstructure analysis of pure $\mathbf{Z n}$ and binary $\mathbf{Z n}$ alloys at the highest alloy contents. a SEM images. Scale bar, $10 \mu \mathrm{m}$. $\mathbf{b} X$-ray diffraction (XRD). $\mathbf{c}$ Chemical composition analysis of intermetallic phases in binary Zn alloys. Error bars indicate mean \pm standard deviation $(n=3)$. Source data are provided as a Source Data file.

corrosion layer formed on $\mathrm{Zn}-0.8 \mathrm{Ca}$ alloy. Precipitates in a much larger size were observed on the surface of the corrosion layer. After the removal of corrosion products, distinct features were observed in different alloy systems (Fig. 3a). The morphology of pure $\mathrm{Zn}$ was complete. In contrast, galvanic corrosion was clearly seen in binary $\mathrm{Zn}$ alloys on a micro scale. Corrosion took place preferentially in the intermetallic phases in $\mathrm{Zn}-0.8 \mathrm{Li}, \mathrm{Zn}-0.8 \mathrm{Mn}$, $\mathrm{Zn}-0.8 \mathrm{Mg}, \mathrm{Zn}-0.8 \mathrm{Ca}$, and $\mathrm{Zn}-0.8 \mathrm{Sr}$ alloys. Among them, corrosion pits were several microns in size and distributed more uniformly in $\mathrm{Zn}-0.8 \mathrm{Li}$ and $\mathrm{Zn}-0.8 \mathrm{Mn}$ alloys, whereas the pits were much larger in $\mathrm{Zn}-0.8 \mathrm{Ca}$ and $\mathrm{Zn}-0.8 \mathrm{Sr}$ alloys. As for $\mathrm{Zn}-0.8 \mathrm{Fe}, \mathrm{Zn}-2.0 \mathrm{Cu}$, and $\mathrm{Zn}-0.8 \mathrm{Ag}$ alloys, their intermetallic phases were almost intact with surrounding $\mathrm{Zn}$ matrix being severe corroded. The second phases protruded apparently in the corroded area in $\mathrm{Zn}-2.0 \mathrm{Cu}$ and $\mathrm{Zn}-0.8 \mathrm{Ag}$ alloys while less difference was seen in $\mathrm{Zn}-\mathrm{Fe}$ alloy. The corrosion rates calculated on weight loss are presented in Fig. 3b. Generally, alloying enhanced the corrosion rate of pure $\mathrm{Zn}$ to varying degrees. Corrosion rates of samples ranged from $0.014 \pm 0.003$ to $0.030 \pm 0.001 \mathrm{~mm}_{\text {year }}{ }^{-1}$ $(n=5)$. In addition, there was an increasing trend in corrosion rates with alloy contents except for $\mathrm{Zn}-\mathrm{Mn}$ and $\mathrm{Zn}-\mathrm{Ag}$ systems. To further depict the influence of alloy elements on corrosion behavior, the corrosion current density versus corrosion potential is shown in Fig. 3c and Supplementary Table 3. In general, there was a negative shift in corrosion potential and an increase in corrosion current density in binary $\mathrm{Zn}$ alloys except for the
Zn-Mn alloy system compared with pure Zn. Among them, Fe, $\mathrm{Cu}$, and $\mathrm{Ag}$ played a more significant role in accelerating corrosion than $\mathrm{Mg}, \mathrm{Ca}, \mathrm{Sr}$, and $\mathrm{Li}$. Mn showed little influence on the corrosion behavior of pure $\mathrm{Zn}$.

Cytocompatibility with MC3T3-E1 cells and HUVEC cells. Osteogenesis and angiogenesis play pivotal roles in skeletal development and bone fracture healing. Therefore, Mouse Osteoblastic Cells (MC3T3-E1) and Human Umbilical Vein Endothelial Cells (HUVECs) were used to evaluate the cytocompatibility of binary $\mathrm{Zn}$ alloys with pure $\mathrm{Zn}$ as control. Figure 4a presents the cell viability of MC3T3-E1 and HUVEC cells cultured in $100 \%$ material extracts. What is striking about the data is that only $\mathrm{Zn}-\mathrm{Mg}$ alloy and $\mathrm{Zn}-\mathrm{Li}$ alloy extracts promoted the proliferation of MC3T3-E1 cells significantly. Whereas pure $\mathrm{Zn}$ and other binary $\mathrm{Zn}$ alloys exhibited severe cytotoxicity except for $\mathrm{Zn}-0.8 \mathrm{Ca}$ and $\mathrm{Zn}-0.1 \mathrm{Sr}$ alloys. After one-fold dilution, no toxicity was found in all groups (Supplementary Fig. 3a). In contrast, HUVEC cells showed better performance on $100 \%$ material extracts (Fig. 4b). Promotion in proliferation was found in pure $\mathrm{Zn}, \mathrm{Zn}-\mathrm{Mg}, \mathrm{Zn}-\mathrm{Ca}, \mathrm{Zn}-\mathrm{Li}, \mathrm{Zn}-\mathrm{Mn}$, and $\mathrm{Zn}-\mathrm{Ag}$ alloy groups while only $\mathrm{Zn}-0.4 \mathrm{Sr}, \mathrm{Zn}-0.1 \mathrm{Fe}, \mathrm{Zn}-0.8 \mathrm{Cu}$, and $\mathrm{Zn}-2.0 \mathrm{Cu}$ showed cytotoxicity on HUVEC cells over time. In order to examine the cell morphology, materials with good cytocompatibility were selected for cell direct contact (Fig. 4b). After $12 \mathrm{~h}$ of 

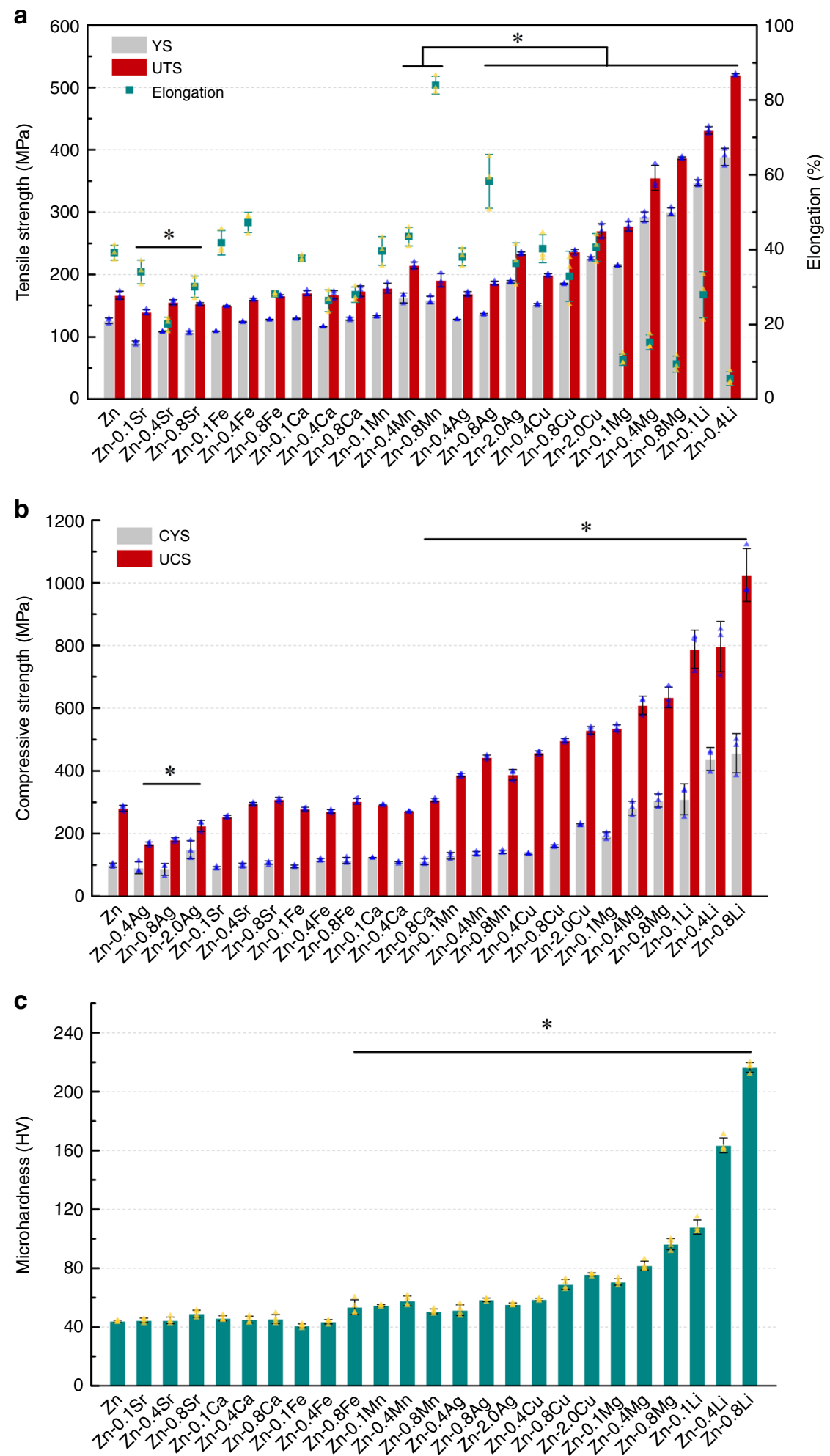

Fig. $\mathbf{2}$ Mechanical performance of pure $\mathbf{Z n}$ and binary $\mathbf{Z n}$ alloys. a Tensile test. $\mathbf{b}$ Compression test. $\mathbf{c}$ Microhardness. Error bars indicate mean \pm standard deviation (tensile and compressive tests, $n=3$; Microhardness, $n=4$, independent samples). ${ }^{\star} P<0.05$ by one-way ANOVA with Tukey's post hoc test, compared with pure $\mathrm{Zn}$. Source data are provided as a Source Data file.

culture on the sample surface, MC3T3-E1 cell displayed a round and unhealthy shape. The F-actin expression was limited and barely distinct from the DAPI signature. In contrast, HUVEC cells exhibited an elongated shape with F-actin filaments extending to the sample surface in all groups except for $\mathrm{Zn}-0.4 \mathrm{Cu}$ and $\mathrm{Zn}-0.8 \mathrm{Ag}$ alloys. Additionally, more F-actin was distributed at the cell edge. Ion concentrations of released $\mathrm{Zn}$ and alloy elements in the culture medium were detected and shown in Supplementary Fig. 3b. There was a decline of $\mathrm{Zn}$ ion concentrations in $\mathrm{Zn}-\mathrm{Ca}$ and $\mathrm{Zn}$-Li alloys compared with pure $\mathrm{Zn}$. In contrast, an apparent increase in $\mathrm{Zn}$ ion concentration was seen in $\mathrm{Zn}-\mathrm{Fe}, \mathrm{Zn}-\mathrm{Cu}$, and $\mathrm{Zn}-\mathrm{Ag}$ alloys. As for alloy elements, 

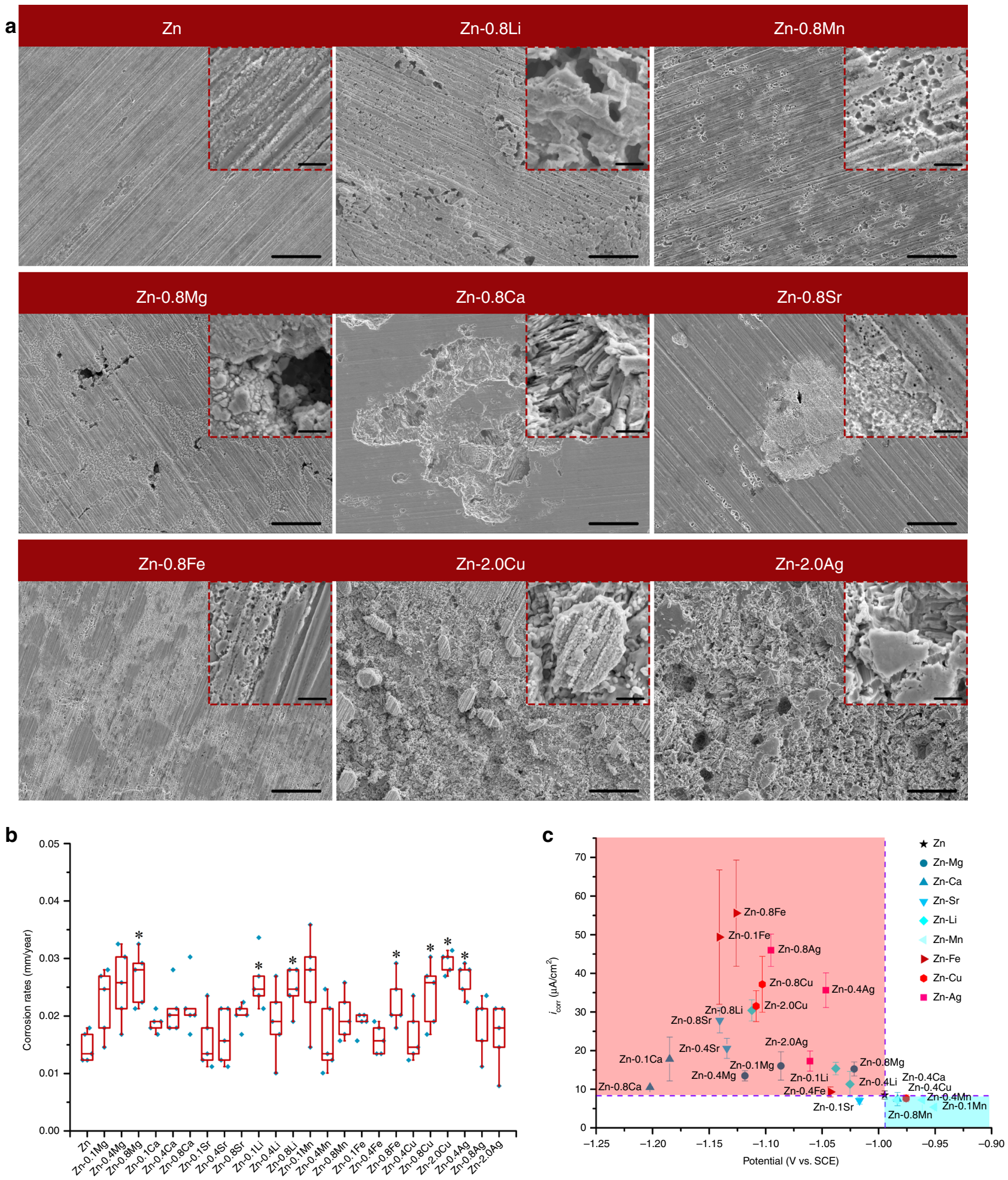

Fig. $\mathbf{3}$ In vitro corrosion behavior of pure $\mathbf{Z n}$ and binary $\mathbf{Z n}$ alloys. a Corrosion morphology of selected materials after removal of corrosion products, intermetallic phases are marked by white arrows. Scale bar, $20 \mu \mathrm{m}$ in low magnification, $2 \mu \mathrm{m}$ in the inserts. $\mathbf{b}$ Corrosion rates calculated on weight loss ( $n=5$, independent samples). ${ }^{\star} P<0.05$ by one-way ANOVA with Tukey's post hoc test, compared with pure Zn. For box-whisker plots, box edges correspond to 25th and 75th percentiles, lines inside the box correspond to 50th percentiles, and whiskers include minimum and maximum of all data points. c Corrosion current density verses corrosion potential based on results of electrochemical test. Error bars indicate mean \pm standard deviation $(n=3$, independent samples). Source data are provided as a Source Data file. 
a
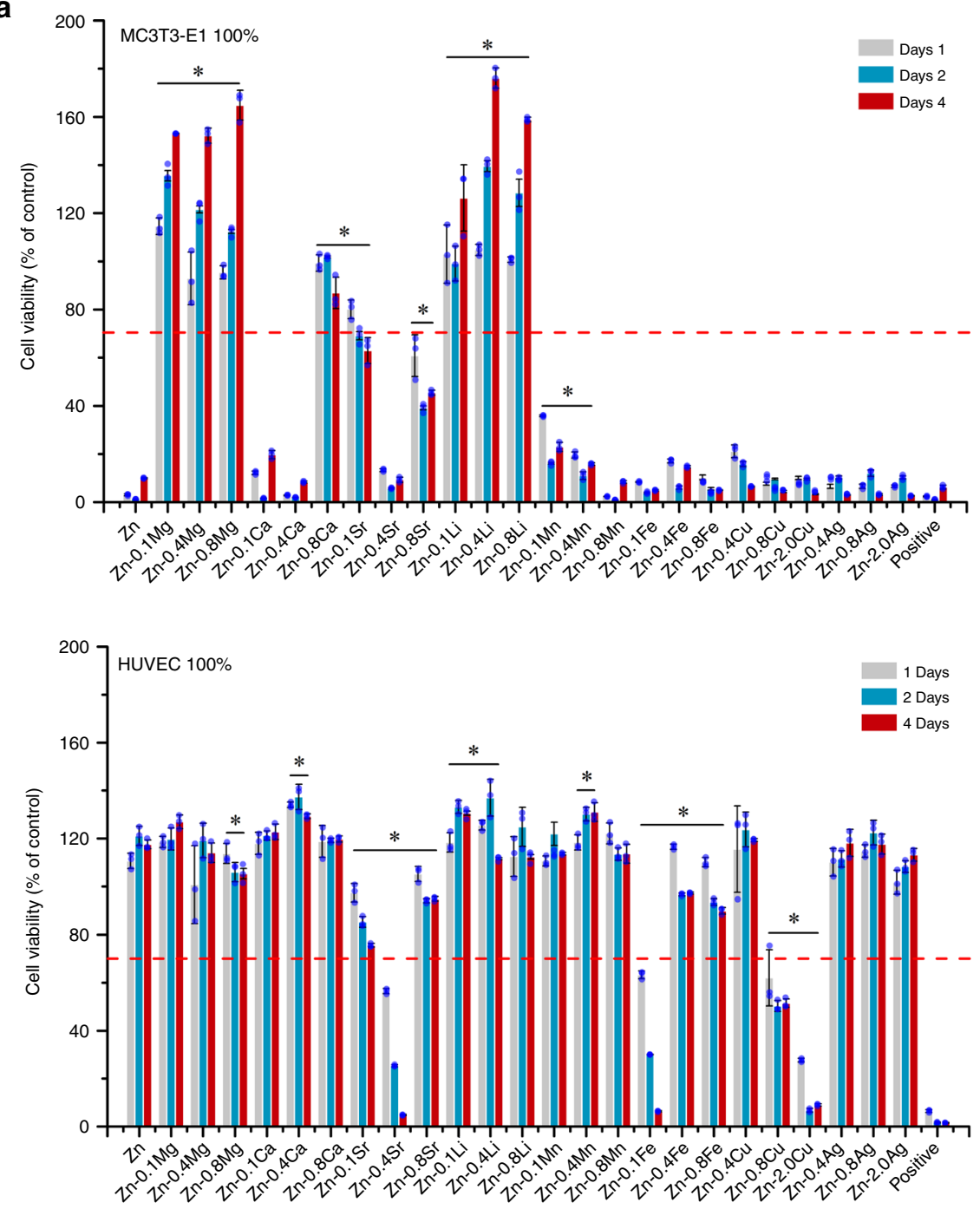

b
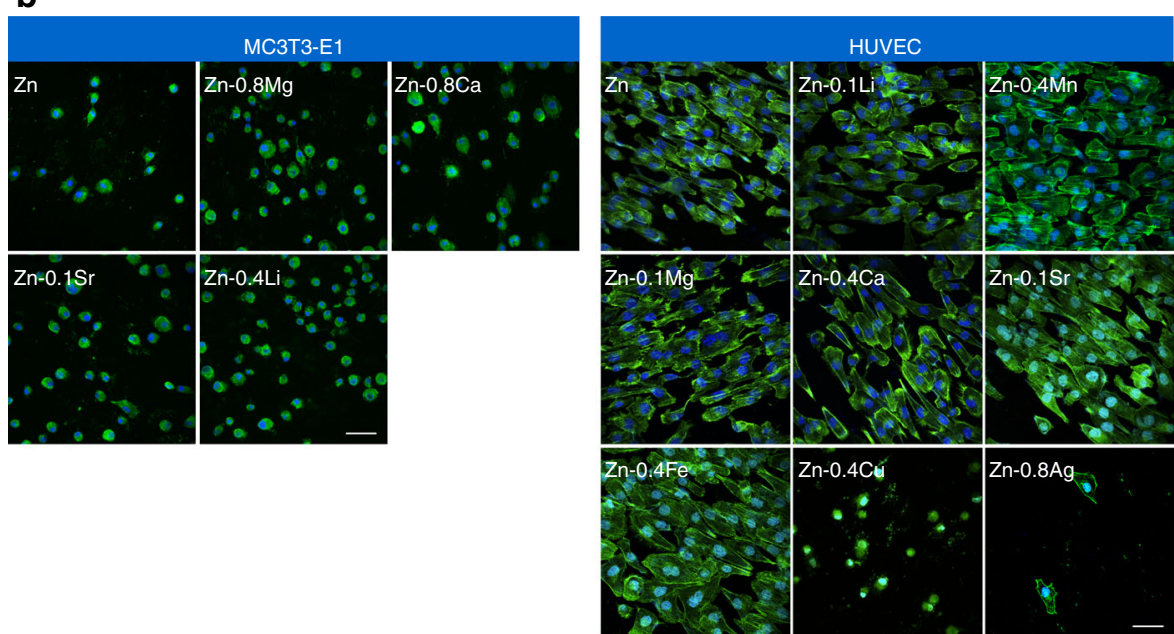

Fig. 4 Cytocompatibility of pure Zn and binary Zn alloys. a Cell viability of MC3T3-E1 cells and HUVEC cells cultured with 100\% extracts. Error bars indicate mean \pm standard deviation $\left(n=3\right.$, independent samples). ${ }^{\star} P<0.05$ by one-way ANOVA with Tukey's post hoc test, compared with pure Zn. The red dashed line indicates the cut-off between non-toxic and toxic responses according to ISO 10993-5. b Fluorescent images of attachment of MC3T3-E1 cells and HUVEC cells on selected sample surfaces at $12 \mathrm{~h}$. Cell nucleus: DAPI, F-actin: FITC. Scale bar, $50 \mu \mathrm{m}$. Source data are provided as a Source Data file. 

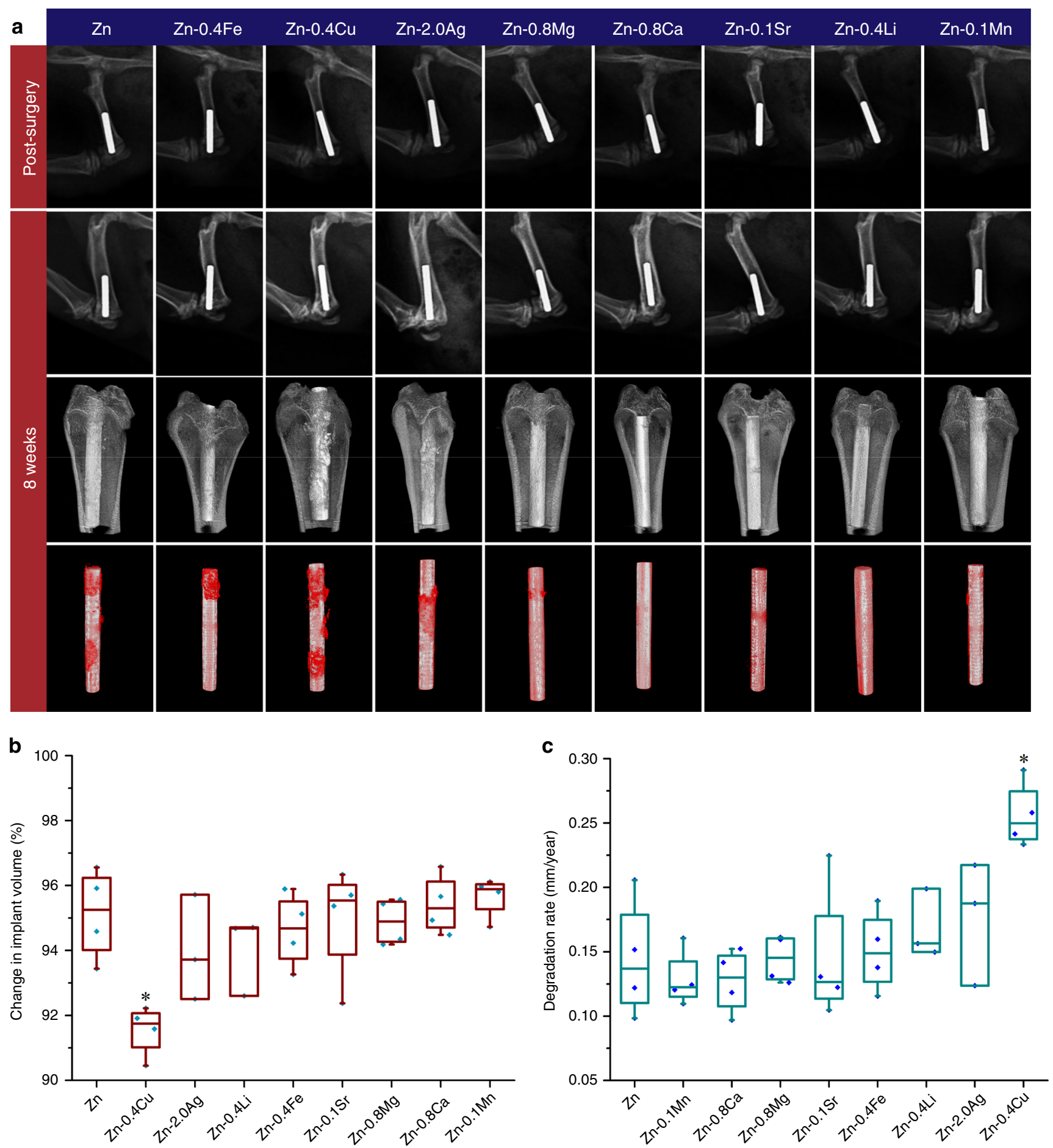

Fig. 5 Micro-CT analysis on degradation behavior of implants. a Radiographs of implants in rat femurs. Post-surgery (first row), 8 weeks after implantation (second row), 8 weeks 3D reconstructions with bone tissue (third row) and 8 weeks 3D reconstructions without bone tissue (fourth row). Degradation products are marked in red. $\mathbf{b}$ Change in implant volume $(n=4$ independent samples). $\mathbf{c}$ In vivo degradation rates $(n=4$, independent samples). For boxwhisker plots, box edges correspond to 25th and 75th percentiles, lines inside the box correspond to 50th percentiles, and whiskers include minimum and maximum of all data points. ${ }^{\star} P<0.05$ by one-way ANOVA with Tukey's post hoc test, compared with Zn. Source data are provided as a Source Data file.

there was a rise in their ion concentrations compared with control. Among them, Ca ion increased about $\sim 10 \mu \mathrm{g} \mathrm{ml}^{-1}$, followed by $\mathrm{Li}$ ion and $\mathrm{Mg}$ ion. The increase in ion concentration was less than $1 \mu \mathrm{g} \mathrm{ml}^{-1}$ in other alloy elements.

In vivo degradation behavior. Binary $\mathrm{Zn}$ alloys with the best cytocompatibility in each alloy system were chosen for the animal test with pure $\mathrm{Zn}$ as control. A rat femur model was utilized to assess the in vivo performance of binary $\mathrm{Zn}$ alloys. Figure $5 \mathrm{a}$ shows the radiographs and reconstructed Micro-CT 3D image of implants post-surgery and at 8 weeks after implantation. All implants displayed distinct X-ray profiles, indicating their excellent radiopacity. Radiographs found no gas shadow in the femoral condyle and bone marrow cavity adjacent to the implants at the 
selected time points. No obvious degradation was detected for all implants at 8 weeks. Interestingly, the cortical bone around the implants became thicker with higher radiographic density over time, indicating the circumferential osteogenesis. All the implants demonstrated good biocompatibility with no signs of osteolysis, deformity or dislocation. Three-dimensional images showed new bone formation and direct contact between new bone and implants at 8 weeks. To evaluate the in vivo degradation behavior of implants, their metallic parts with degradation products were reconstructed. Generally, all the implants maintained their integrity at 8 weeks. Among them, pure $\mathrm{Zn}, \mathrm{Zn}-0.4 \mathrm{Fe}, \mathrm{Zn}-0.4 \mathrm{Cu}$, and $\mathrm{Zn}-2.0 \mathrm{Ag}$ alloy implants displayed a localized degradation mode with local accumulation of products. In contrast, degradation of $\mathrm{Zn}-0.8 \mathrm{Mg}$, Zn-0.8Ca, Zn-0.1Sr, Zn-0.4Li, and Zn-0.1Mn was more uniform on a macro scale. Volume change and degradation rate of implants were quantitatively measured and shown in Fig. 5b, c. At 8 weeks, the volume of pure $\mathrm{Zn}$ implant dropped to $95.12 \pm 1.39 \%(n=4)$ and its degradation rate was $0.14 \pm 0.05 \mathrm{~mm}$ year $^{-1}(n=4)$. By contrast, $\mathrm{Zn}-0.4 \mathrm{Cu}$ alloys displayed a significant higher degradation rate of $0.26 \pm 0.03 \mathrm{~mm}$ year $^{-1}(n=4)$. Moreover, accelerated degradation was observed in $\mathrm{Zn}-2.0 \mathrm{Ag}, \mathrm{Zn}-0.4 \mathrm{Li}, \mathrm{Zn}-0.4 \mathrm{Fe}$, and $\mathrm{Zn}-0.8 \mathrm{Mg}$ alloys while $\mathrm{Zn}-0.1 \mathrm{Mn}, \mathrm{Zn}-0.8 \mathrm{Ca}$, and $\mathrm{Zn}-0.8 \mathrm{Sr}$ alloys exhibited similar degradation rates to that of pure $\mathrm{Zn}$.

To further understand the degradation of $\mathrm{Zn}$ implants, the bone-implant interface was examined based on SEM and EDS on a micro level. Figure 6 a presents the representative crosssections containing both implants and surrounding tissue. The remaining metallic implants were visible as spherical features surrounding by degradation products and tissue. By matching the Micro-CT results, implants could be divided into two categories based on their degradation morphology. The first category contains specimens displaying extensive localized corrosion, such as pure $\mathrm{Zn}$, and $\mathrm{Zn}-0.4 \mathrm{Fe}, \mathrm{Zn}-0.4 \mathrm{Cu}$, and $\mathrm{Zn}-2.0 \mathrm{Ag}$ alloys. The second category, which is the rest of the tested lot, contains those specimens exhibiting uniform corrosion and maintained an intact spherical cross-section. The typical bone-implant interface in each group was selected and examined by SEM and elemental mapping with pure $\mathrm{Zn}$ as control (Fig. 6b). Severe, localized corrosion created some pits with depths of tens of microns in pure $\mathrm{Zn}$ implant. Degradation products penetrated into the implant and diffused into the surrounding tissue simultaneously. Direct contact between newly formed bone and degradation products was found in some local sites. Compositional analysis demonstrated that $\mathrm{Zn}$ and $\mathrm{O}$ were the major elements detected in degradation products while $\mathrm{Ca}$ and $\mathrm{P}$ were rich in new bone tissue. In contrast, the bone-implant interface in $\mathrm{Zn}-0.4 \mathrm{Li}$ alloy was much clear. A shallow, evenly distributed feature with small corroded dimples was observed in this group. As for the $\mathrm{Zn-2.0Ag}$ alloy, some locations appeared to be heavily attacked. Corrosion penetrated inside with a depth of over $50 \mu \mathrm{m}$. Interestingly, there were some Ag containing second phases in the corrosion interface left uncorroded. Additionally, new bone was found lying on the degradation products as well. Figure $6 \mathrm{c}$ presents the chemical compositions of representative regions in Fig. $6 \mathrm{~b}$. Region I was the metallic matrix. Degradation products were composed of three different chemical compositions including region II to IV. Region II, as the main components of degradation products, mainly contained $\mathrm{C}, \mathrm{O}$, and $\mathrm{Zn}$. $\mathrm{Ca}$ and $\mathrm{P}$ arose in region III that usually found in the outer layer of degradation products. Region IV had a similar composition to that of the surrounding bone. The $\mathrm{Ca} / \mathrm{P}$ ratio increased from 0.45 of region III to 1.03 of region IV while $\mathrm{Zn}$ content decreased from $13.15 \pm 4.21 \%(n=15)$ to $5.23 \pm 2.77 \%(n=4)$. Two inorganic compositions were detected in new bone tissue as well including regions $\mathrm{V}$ and $\mathrm{VI}$. The $\mathrm{Ca} / \mathrm{P}$ ratio of region $\mathrm{V}$ and region VI was 1.09 and 1.37, respectively. Meanwhile, Zn content decreased from $8.96 \pm 3.00 \%(n=9)$ of region $\mathrm{V}$ to 1.04 $\pm 0.52 \%(n=24)$ of region VI.

Osteogenesis and osseointegration. Representative cross-sections of implants at 8 weeks were stained with van Gieson to evaluate their osteogenic and bone integration ability (Fig. 7a). New bone tissue formed around all the implants with different morphologies. Similarly, two categories with distinct features could be observed by histological analysis. In pure $\mathrm{Zn}, \mathrm{Zn}-0.4 \mathrm{Fe}, \mathrm{Zn}-0.4 \mathrm{Cu}$, and $\mathrm{Zn}$ $2.0 \mathrm{Ag}$ alloys, dark brown degradation products spread into the surrounding tissue with newly formed woven bone dispersed in it. In contrast, larger amounts of new bone tissue could be observed surrounding the implants continuously in $\mathrm{Zn}-0.4 \mathrm{Li}, \mathrm{Zn}-0.1 \mathrm{Mn}$, $\mathrm{Zn}-0.8 \mathrm{Mg}, \mathrm{Zn}-0.8 \mathrm{Ca}$, and $\mathrm{Zn}-0.1 \mathrm{Sr}$ alloys. Moreover, the osteocytes in the new bone tissue arranged in a more organized way, indicating a more mature status. The new bone area (BA) adjacent to the implants were analyzed quantitatively (Fig. $7 \mathrm{~b}$ ). $\mathrm{Zn}-0.1 \mathrm{Sr}$, $\mathrm{Zn}-0.8 \mathrm{Ca}$, and $\mathrm{Zn}-0.8 \mathrm{Mg}$ alloys exhibited significant higher new bone area than that of pure $\mathrm{Zn}$ followed by $\mathrm{Zn}-0.1 \mathrm{Mn}, \mathrm{Zn}-0.4 \mathrm{Li}$, $\mathrm{Zn}-2.0 \mathrm{Ag}$, and $\mathrm{Zn}-0.4 \mathrm{Cu}$ alloys. As for osseointegration, direct bone bonding to implants in local sites was found in all the groups. Among them, pure $\mathrm{Zn}, \mathrm{Zn}-0.4 \mathrm{Fe}, \mathrm{Zn}-0.4 \mathrm{Cu}$, and $\mathrm{Zn}-2.0 \mathrm{Ag}$ alloy groups showed thicker intervening fibrous layers than other groups. In contrast, implants were closely integrated with new bone tissue in $\mathrm{Zn}-0.1 \mathrm{Sr}, \mathrm{Zn}-0.8 \mathrm{Ca}, \mathrm{Zn}-0.4 \mathrm{Li}$, and $\mathrm{Zn}-0.8 \mathrm{Mg}$ alloy groups, showing better bone integration ability. Quantitatively analysis (Fig. 7c) elucidated that $\mathrm{Zn}-0.1 \mathrm{Sr}$ and $\mathrm{Zn}-2.0 \mathrm{Ag}$ alloys exhibited a significant higher bone-implant contact ratio (BIC) than that of pure $\mathrm{Zn}$ followed by $\mathrm{Zn}-0.8 \mathrm{Ca}, \mathrm{Zn}-0.4 \mathrm{Li}$, and $\mathrm{Zn}-0.8 \mathrm{Mg}$ alloys. Unlike $\mathrm{Zn}-0.1 \mathrm{Sr}$, the new bone tissue in $\mathrm{Zn}-2.0 \mathrm{Ag}$ displayed a shattered feature. The $\mathrm{BIC}$ of $\mathrm{Zn}-0.4 \mathrm{Cu}$ and $\mathrm{Zn}-0.4 \mathrm{Fe}$ alloys decreased significantly. The $\mathrm{Zn}$ ion concentration in blood serum was collected at 8 weeks and shown in Fig. 7d. No significant difference was found in $\mathrm{Zn}$ ion values for all the implant groups compared with the control group.

\section{Discussion}

The mechanical property, biodegradability, and biocompatibility are necessary and sufficient criteria for materials being regarded as biodegradable bone implants. Mg-based orthopedic devices have received extensive studies and been transferred to clinical use successfully. Table 1 compares the major parameters between biodegradable $\mathrm{Zn}$-based materials and $\mathrm{Mg}$-based materials regarding the aspects mentioned above. For mechanical property, the tensile strength of as extruded $\mathrm{Mg}$ alloys was usually lower than $350 \mathrm{MPa}$. Meanwhile, the elongation to failure ranged from 8 to $28 \%$. In contrast, the maximum tensile strength of as extruded $\mathrm{Zn}$ alloys in this study reached $520 \mathrm{MPa}(\mathrm{Zn}-0.4 \mathrm{Li}$ alloy). And the elongation to failure was observed from $6 \%$ up to $84 \%$. The tensile strength of $\mathrm{Zn}-\mathrm{Li}$ and $\mathrm{Zn}-\mathrm{Mg}$ alloy systems were able to exceed $400 \mathrm{MPa}$ easily by hot extrusion or rolling ${ }^{14}$. And the elongation of $\mathrm{Zn}-\mathrm{Mn}, \mathrm{Zn}-\mathrm{Cu}$, and $\mathrm{Zn}-\mathrm{Ag}$ alloy systems was higher than $30 \%$. Significantly higher values could be seen in compressive strength, microhardness, and elastic modulus as well. An ideal implant should provide adequate strength or at least match the mechanical property of the bone, referred to as biomechanical compatibility. Thus, a material with an excellent combination of high strength and low modulus closer to the bone is desired for bone implants. Biodegradable $\mathrm{Zn}$ alloys possess higher modulus than bone that usually varies from 4 to $30 \mathrm{GPa}^{33}$. However, considering the loss of mechanical integrity over time, whether the "stress shielding effect" will be a concern for biodegradable $\mathrm{Zn}$-based bone implants still needs further study. 

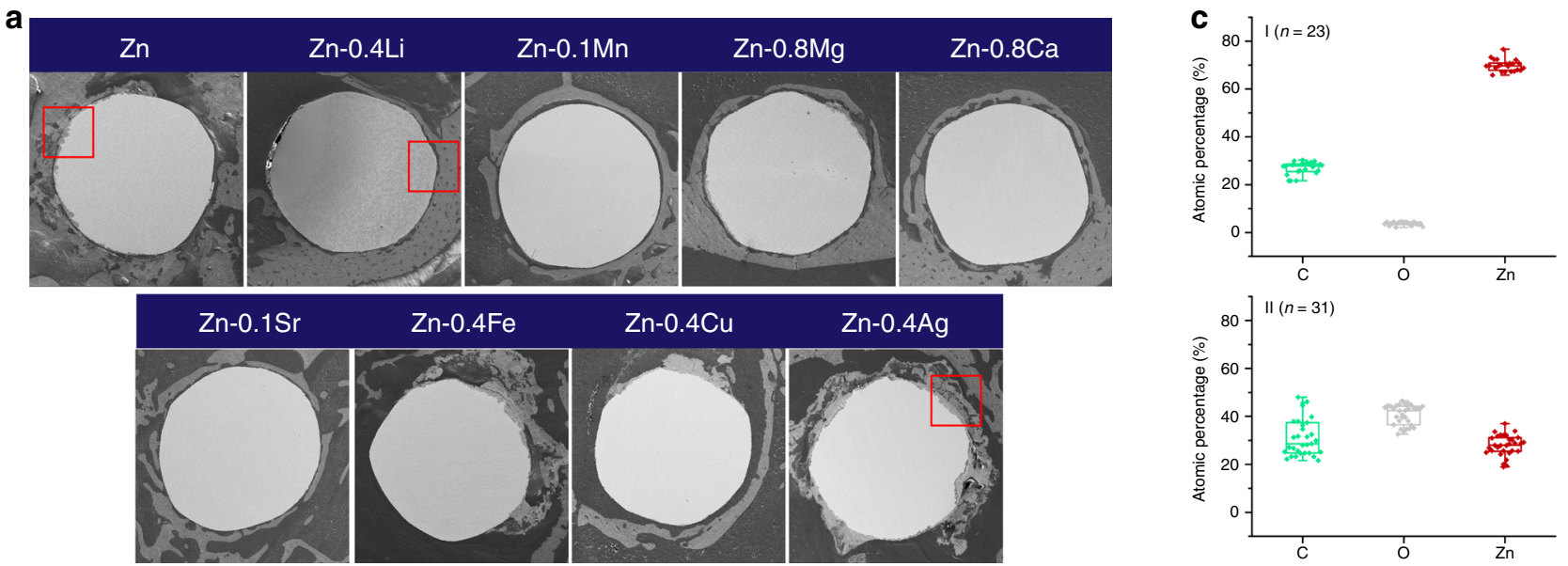

b
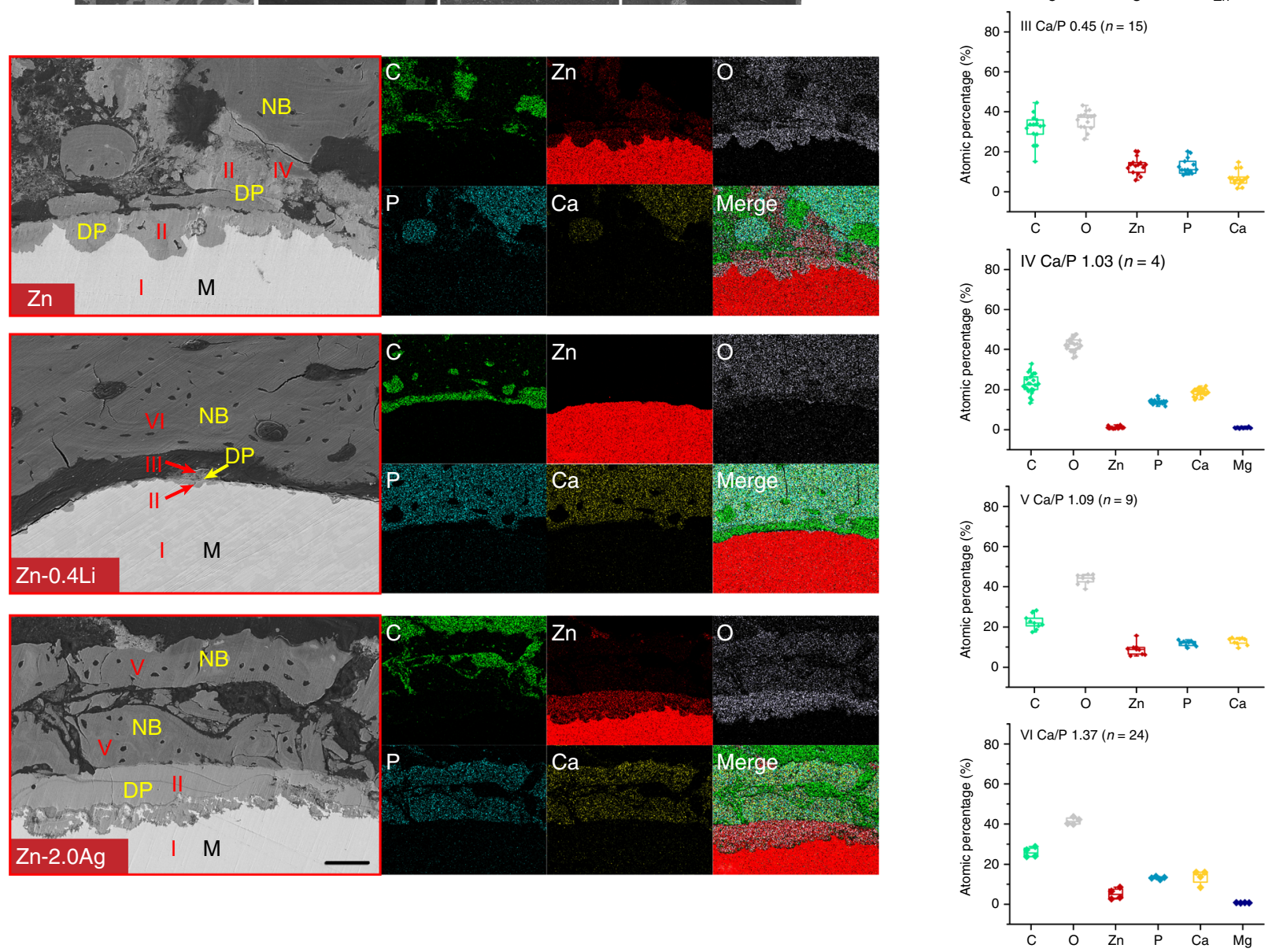

Fig. 6 Cross sectional analysis on degradation behavior of implants. a Cross sectional images of implants. Scale bar, $0.5 \mathrm{~mm}$. b Magnification of red rectangles in a with representative bone-implant interface and corresponding elemental mappings. NB: new bone; DP: degradation products; M: matrix. Scale bar, $50 \mu \mathrm{m}$. c Chemical compositions of marked regions in $\mathbf{b}$ ( $n$ values are shown in the figures, independent samples). For box-whisker plots, box edges correspond to 25th and 75th percentiles, lines inside the box correspond to 50th percentiles, and whiskers include minimum and maximum of all data points. Source data are provided as a Source Data file.

Better mechanical performance enables biodegradable Zn-based materials to have more potential applications in some loadbearing sites compared to biodegradable Mg-based materials.

Distinct features between $\mathrm{Zn}$ and $\mathrm{Mg}$ can be observed regarding biodegradability. In general, $\mathrm{Mg}$ and its alloys display much higher degradation rates than that of $\mathrm{Zn}$ and its alloys both in vitro and in vivo. The degradation rates of $\mathrm{Mg}$ and its alloys in rat femur are one to twelve folds faster than that of $\mathrm{Zn}$ and its alloys. And the difference is amplified by immersion and electrochemical tests. The bone healing time varies for different fracture sites, and the mechanical support provided by implants should be sustained for 12-24 weeks depending on the clinical conditions ${ }^{6}$. Clinical trials reported the complete degradation of $\mathrm{Mg}$ alloy screws at 6 and 12 months ${ }^{3,4}$, which seems to meet the degradation requirement. However, the clinical results of $\mathrm{Mg}$ alloy screws are limited in non or low-load bearing sites. Therefore, it is hard to judge whether $\mathrm{Mg}$ alloy screws are able to provide sufficient support in high load-bearing sites. In light of 
a
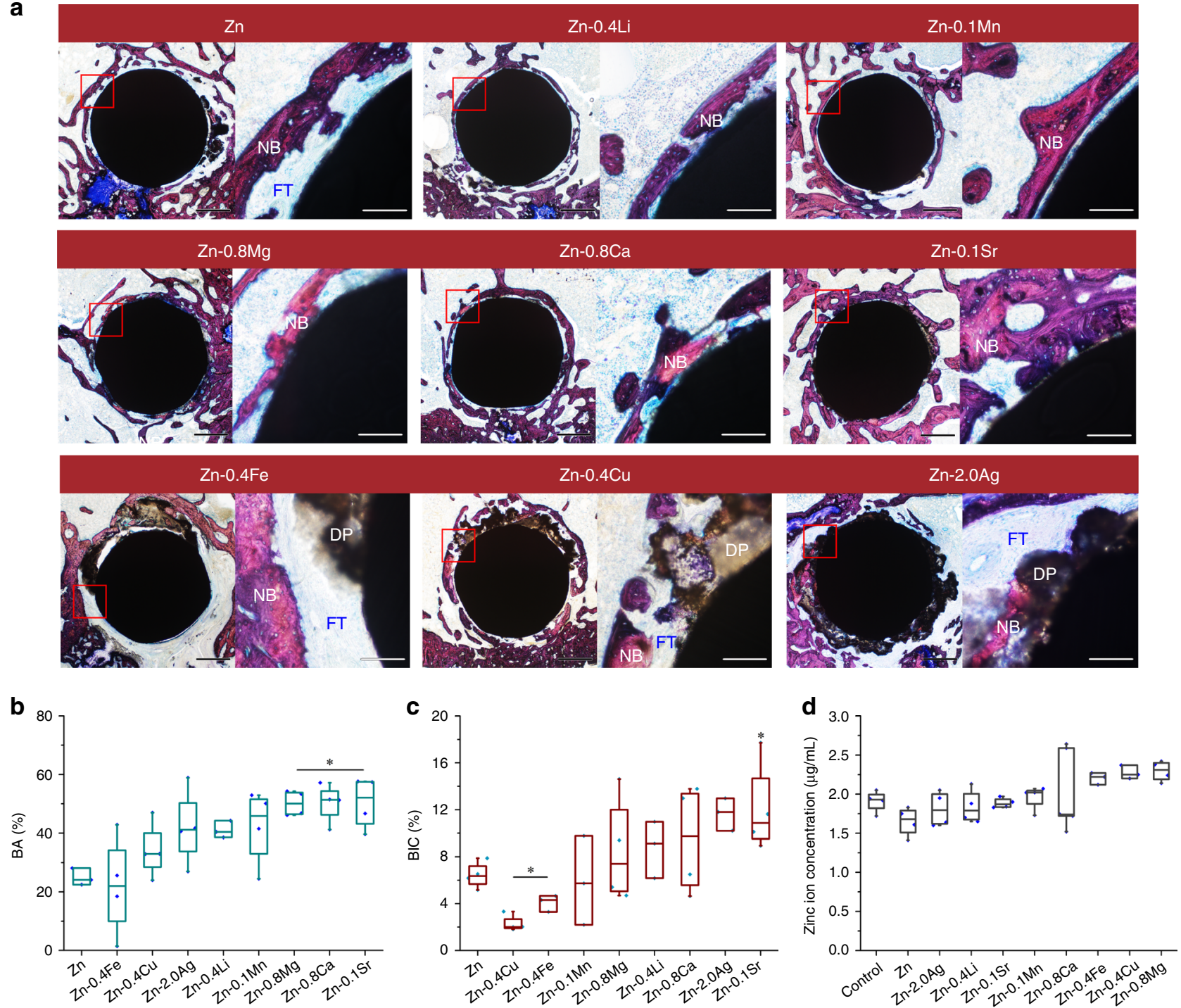

Fig. 7 Histological analysis on osteogenesis and osseointegration at 8 weeks. a Van Gieson staining of representative cross sections in metaphysis, the magnified region is marked by red rectangle. NB, new bone; DP, degradation products; FT, fibrous tissue. Scale bar, $0.5 \mathrm{~mm}$ in low magnification, $500 \mu \mathrm{m}$ in high magnification. $\mathbf{b}$ New bone area surrounding the implants, ${ }^{\star} P<0.05$, compared with $\mathrm{Zn}(n=4$, independent samples). c Bone-implant contact ratio, ${ }^{\star} P<0.05$, compared with $\mathrm{Zn}\left(n=4\right.$, independent samples). d Zinc ion concentration in blood serum at 8 weeks, ${ }^{\star} P<0.05$, compared with control ( $n=4$, independent samples). ${ }^{\star} P<0.05$ by one-way ANOVA with Tukey's post hoc test. For box-whisker plots, box edges correspond to 25 th and 75 th percentiles, lines inside the box correspond to 50th percentiles, and whiskers include minimum and maximum of all data points. Source data are provided as a Source Data file.

this, $\mathrm{Zn}$ and its alloys are able to maintain mechanical integrity for longer implantation time and prevent early mechanical failure during service. Degradation of $\mathrm{Mg}$ and $\mathrm{Zn}$ enables a series of reactions within the physiological environment leading to the formation of gaseous, solid and soluble products. Hydrogen gas is a typical product for $\mathrm{Mg}$ and its alloys due to hydrogen evolution reaction during corrosion. Clinical studies reported acceptable outcomes considering gas formation during degradation of $\mathrm{Mg}$ alloy bone implants ${ }^{3,4}$. However, excessive hydrogen gas can interfere with the bone healing process, resulting in callus formation and cortical defects ${ }^{34}$. In contrast, X-ray image, Micro$\mathrm{CT}$, and histology showed no sign of gas formation around $\mathrm{Zn}$ and its alloys in this study. Oxygen reduction reaction should be the primary cathodic reaction of zinc in the neutral physiological environment. The dissolved oxygen influences the corrosion of zinc in the $\mathrm{pH}$ range from 4 to 12 , which applies to most of the potential implantation sites in the human body ${ }^{35}$.
Therefore, similar to the biodegradation of iron ${ }^{36}$, the availability of oxygen plays a critical role in the degradation of $\mathrm{Zn}$ and its alloys ${ }^{37}$. Hydroxyl ions and metal ions are released during the degradation, leading to the increase of local $\mathrm{pH}$. Corrosion of $\mathrm{Mg}$ results in a more pronounced $\mathrm{pH}$ increase compared with $\mathrm{Zn}^{9}$. The simultaneous increase in $\mathrm{pH}$ and metal ion concentrations will lead to the precipitation of oxides and hydroxides. The solubility product constants $\left(K_{\mathrm{sp}}\right)$ of $\mathrm{Zn}(\mathrm{OH})_{2}$ and $\mathrm{ZnO}$ are much lower than that of $\mathrm{Mg}(\mathrm{OH})_{2}$ and $\mathrm{MgO}$, indicating a longer dissolution and absorption period in the bone environment. Calcium phosphate is another major product when $\mathrm{pH}$ increases. The previous study has reported the formation of calcification matrix, the crystalline calcium phosphate phase with a similar bone-like structure, in the Mg-bone interface. The calcification matrix is further resorbed by osteoclasts and utilized by osteoblasts to form new bone $e^{4,38}$. In this study, we identified the product (region IV in Fig. 6b) with a similar chemical composition to that of adjacent 
Table 1 Comparison of key properties between $\mathrm{Zn}$-based and $\mathrm{Mg}$-based biodegradable metals.

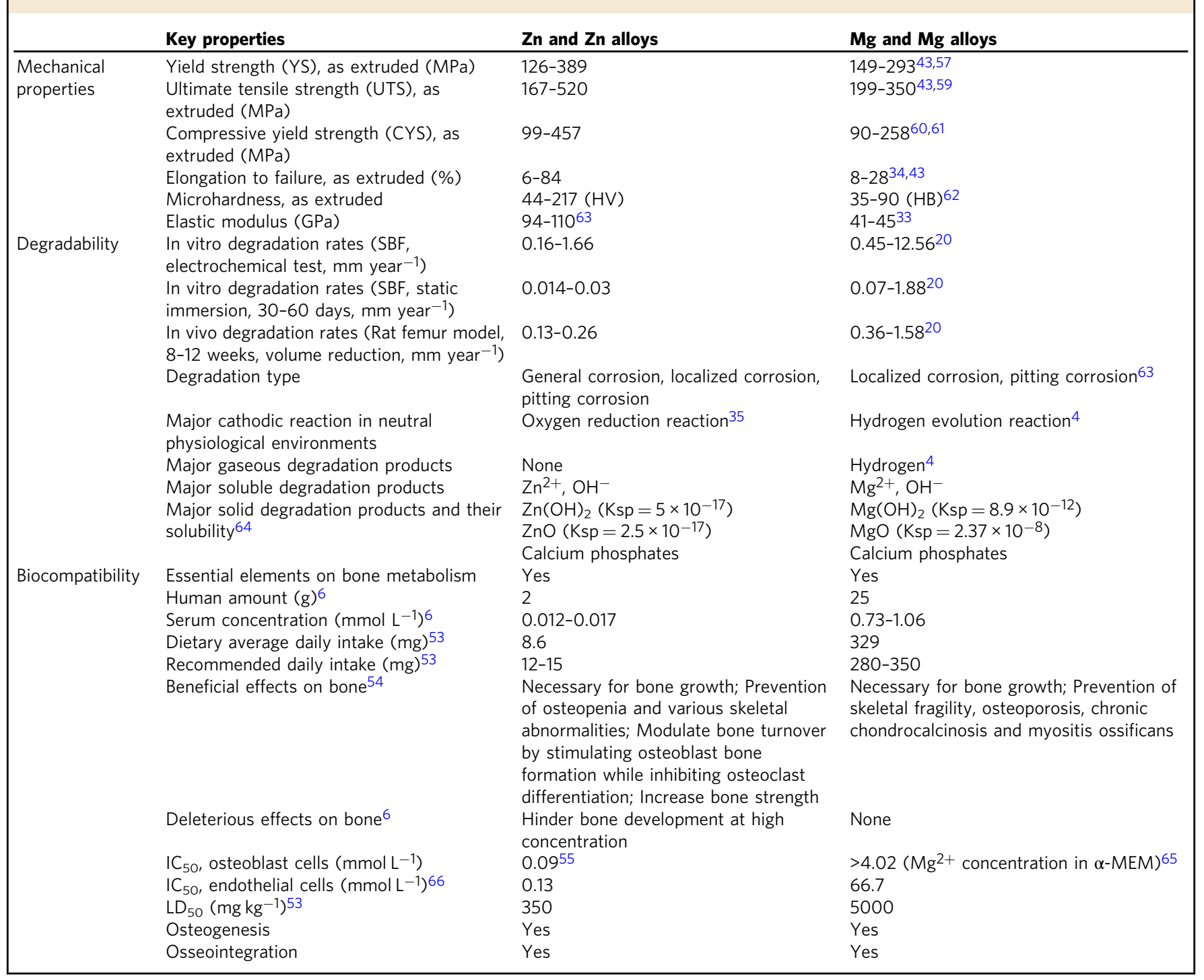

new bone. Additionally, a type of new bone tissue (region $\mathrm{V}$ in Fig. 6b) with a relatively low $\mathrm{Ca} / \mathrm{P}$ ratio and high $\mathrm{Zn}$ content was detected as well. Thus, it's reasonable to speculate that the degradation of Zn-based implants should have a similar bone formation aiding mechanism to that of $\mathrm{Mg}$-based implants.

Both $\mathrm{Zn}$ and $\mathrm{Mg}$ are essential elements on bone metabolism, but their contents in the human body and threshold values for daily intake vary greatly. The human body has a much greater demand for $\mathrm{Mg}$ than $\mathrm{Zn}$. Therefore, $\mathrm{Zn}$ exhibits a more significant dose-dependent effect on cellular and tissue biocompatibility than $\mathrm{Mg}$ at relatively low concentrations. Most of the $100 \%$ extracts of $\mathrm{Zn}$ and its alloys showed significant cytotoxicity on MC3T3-E1 cells while no cytotoxicity was found in all groups after one-fold dilution. And the $\mathrm{Zn}$ ion concentrations in $100 \%$ extracts only ranged from 10 to $25 \mu \mathrm{g} \mathrm{mL}-1$. Moreover, endothelial cells are better tolerant of $\mathrm{Zn}$ than osteoblast cells. Several studies found a dose-dependent effect of $\mathrm{Zn}^{2+}$ on cell viability, proliferation, spreading and migration ${ }^{19,39,40}$. Generally, low concentrations of $\mathrm{Zn}^{2+}$ promoted the viability, proliferation, adhesion and migration of osteoblast cells, endothelial cells, and vascular smooth muscle cells, while high concentrations of $\mathrm{Zn}^{2+}$ had opposite effects. Mg-based implants have been evaluated by extensive studies in bone environments with different animal models ${ }^{6,41}$. Most of the research reported enhanced new bone formation around the Mg-based implants including promoted local periosteal and endosteal bone formation. As for osseointegration, slow degraded $\mathrm{Mg}$-based implants usually showed direct contact between degradation products and new bone ${ }^{42-44}$. Whereas the presence of fibrous tissue was found in fast degraded ones $^{45,46}$. In contrast, newly formed bone was observed surrounding $\mathrm{Zn}$-based implants at 8 weeks (Fig. 7). And the boneimplant contact ratio (BIC) varied depending on the degradation behavior of implants. Uniform corrosion mode with appropriate degradation rates resulted in improved BIC, while severe localized corrosion provoked a thick fibrotic layer surrounding the implants. Therefore, both $\mathrm{Zn}$-based and $\mathrm{Mg}$-based implants indicate good biocompatibility in bone environments. For Zn-based implants, the concentrations of degradation products should be restricted within a safe threshold to prevent their detrimental effects at high concentrations.

In order to achieve optimized material properties as bone implants, the alloying design strategy for biodegradable $\mathrm{Zn}$ alloys is proposed here considering mechanical property, biodegradability, and biocompatibility:

Alloying with $\mathrm{Li}, \mathrm{Mg}, \mathrm{Cu}, \mathrm{Ag}$, and $\mathrm{Mn}(\leq 2 \mathrm{wt} \%)$ resulted in a significant increase in strength and hardness. Among them, 

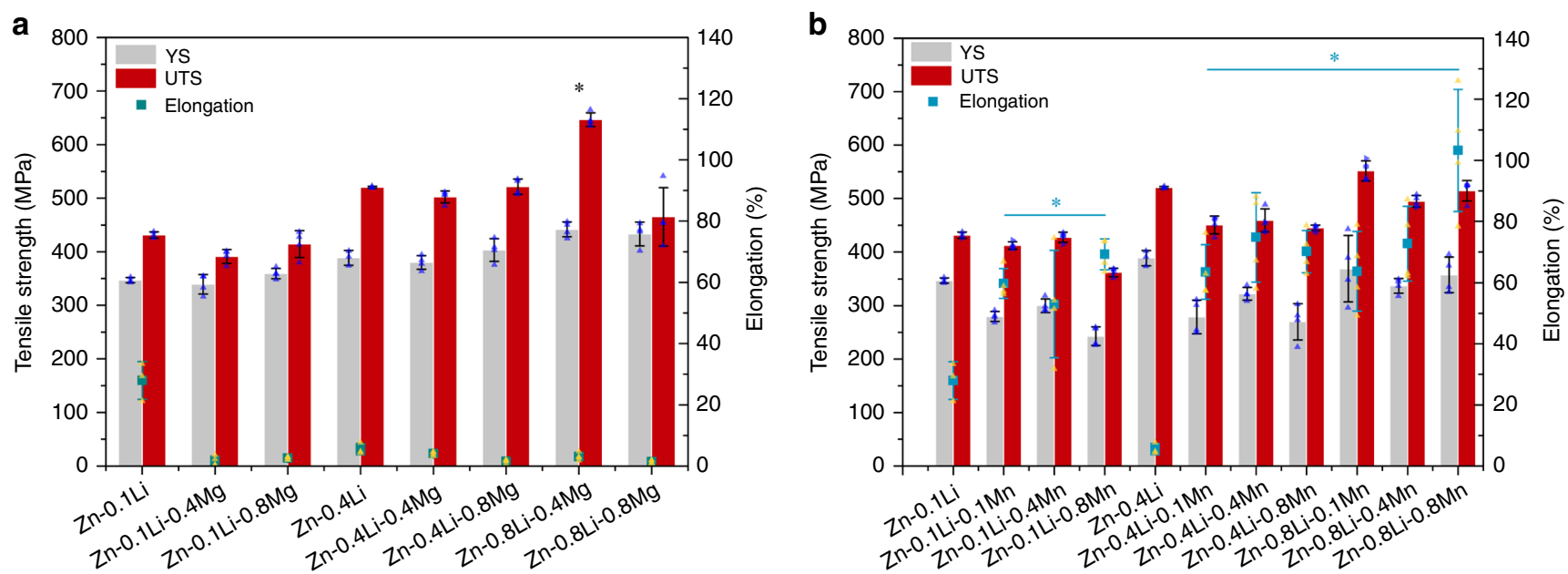

Fig. 8 Mechanical properties of biodegradable ternary $\mathbf{Z n}$ alloys. a $\mathrm{Zn}-\mathrm{Li}-\mathrm{Mg}$ alloy, ${ }^{\star} P<0.05$, compared with $\mathrm{Zn}-0.4 \mathrm{Li}$ alloy. $\mathbf{b} \mathrm{Zn}-\mathrm{Li}-\mathrm{Mn}$ alloy, ${ }^{\star} P<0.05$, compared with $\mathrm{Zn}-0.1 \mathrm{Li}$ alloy. Error bars indicate mean \pm standard deviation $\left(n=4\right.$, independent samples). ${ }^{*} P<0.05$ by one-way ANOVA with Tukey's post hoc test. Source data are provided as a Source Data file.

Li displayed the best strengthening effect on $\mathrm{Zn}$ followed by $\mathrm{Mg}$. The strengthening mechanism of $\mathrm{Li}$ and $\mathrm{Mg}$ can be attributed to the grain refinement and intermetallic phases considering the low solubility of these elements in $\mathrm{Zn}^{9,11,47}$. The pinning effects caused by a high density of fine dispersive $\mathrm{LiZn}_{4}$ precipitates $(10-30 \mathrm{~nm})$ played a major role in increasing the strength of $\mathrm{Zn}-\mathrm{Li}$ alloys ${ }^{48}$. Naturally, strengthening always comes with a reduction in ductility. However, no detrimental effect on ductility was found after adding $\mathrm{Cu}$ and $\mathrm{Ag}$. And alloying with $\mathrm{Mn}$ resulted in a superb elongation compared with other $\mathrm{Zn}$ alloys. Apart from the solid solution and refined grain, tensile twin was a key factor affecting the mechanical property of as-extruded $\mathrm{Zn}-\mathrm{Mn}$ alloys ${ }^{49}$. Although $\mathrm{Ca}$ and $\mathrm{Sr}$ showed no strengthening effect on $\mathrm{Zn}$ in this study, an increased tensile strength of $\mathrm{Zn}-\mathrm{Ca}, \mathrm{Zn}-\mathrm{Sr}$, and $\mathrm{Zn}-\mathrm{Fe}$ alloys with higher contents were observed elsewhere ${ }^{16,50}$.

Alloying with selected elements here increased the degradation rates of $\mathrm{Zn}$ to varying degrees. Galvanic corrosion was observed in all binary $\mathrm{Zn}$ alloys with intermetallic phases. $\mathrm{Zn}$ acted as the anode in $\mathrm{Zn}-\mathrm{Fe}, \mathrm{Zn}-\mathrm{Cu}$, and $\mathrm{Zn}-\mathrm{Ag}$ alloys while $\mathrm{Zn}$ was the cathode in other alloys. Among them, $\mathrm{Cu}$ and $\mathrm{Ag}$ showed the most significant effect on accelerating degradation. Adding Fe, $\mathrm{Cu}$, and $\mathrm{Ag}$ resulted in severe localized corrosion in the rat femur. Whereas uniform corrosion was dominant in other binary alloy systems. According to the bone healing time for different fractures, bone implants are suggested to maintain mechanical integrity for at least 3-6 months. The volume loss of pure $\mathrm{Zn}$ and its alloys was less than $10 \%$ at 8 weeks, indicating the complete degradation of them may need at least 20 months based on a linear degradation trend. Therefore, a faster degradation rate should be more appropriate. However, efforts should be made to establish a more accurate and reasonable standard for degradation through animal or even clinical tests. Apart from this, it is critical to control the concentration of degradation products within a beneficial range during the degradation of $\mathrm{Zn}$-based implants. To achieve the accelerated and controlled degradation simultaneously, elements with lower electrode potentials should be considered preferentially as alloying elements to $\mathrm{Zn}$. The second phases formed between $\mathrm{Zn}$ and these elements will act as anodes and, consequently, creating galvanic couples. As a result, accelerating the overall corrosion while inhibiting the corrosion of the $\mathrm{Zn}$ matrix can be expected.

Alloying with $\mathrm{Li}$ and $\mathrm{Mg}$ exhibited the most distinct effect in improving the cytocompatibility of $\mathrm{Zn}$. Moreover, adding $\mathrm{Ca}$ and
Sr with appropriate content was able to eliminate the toxicity of $\mathrm{Zn}$ as well. More importantly, enhanced new bone formation and bone integration ability were observed after alloying with $\mathrm{Mg}, \mathrm{Ca}$, $\mathrm{Sr}$, and Li. Among them, Sr showed the most significant effect in improving the performance of $\mathrm{Zn}$. It is well known that $\mathrm{Ca}$ and $\mathrm{Mg}$ are essential elements that play pivotal roles in bone health ${ }^{21,22}$. Sr stimulated osteoblast replication and differentiation and increased cell survival under stress ${ }^{51,52}$. Li improved bone mass in mice and enhanced bone formation via activation of the canonical Wnt pathway ${ }^{25}$. And maintenance therapy with lithium carbonate enhanced bone mass ${ }^{26}$. Therefore, elements that play essential or beneficial roles in bone metabolism can be regarded as potential alloying elements. Metallic elements $(\mathrm{K}, \mathrm{Na}$, $\mathrm{Ba}$, and $\mathrm{Mo})$ and nonmetallic elements $(\mathrm{O}, \mathrm{P}, \mathrm{S}, \mathrm{Si}$, and $\mathrm{Se})$ can be added into $\mathrm{Zn}$ to develop novel $\mathrm{Zn}$ alloy systems for better biocompatibility in the future ${ }^{53-55}$.

Based on the above discussion, $\mathrm{Zn}-\mathrm{Li}, \mathrm{Zn}-\mathrm{Mg}, \mathrm{Zn}-\mathrm{Ca}$, and $\mathrm{Zn}-\mathrm{Sr}$ alloy systems displayed the most desirable comprehensive properties for developing Zn-based bone implants. Material optimization including multi-alloy systems and composites and device design can be further developed based on these alloy systems. Among them, the $\mathrm{Zn}-\mathrm{Li}$ alloy system exhibited the greatest potential to be used for load-bearing applications. Therefore, we further designed ternary $\mathrm{Zn}-\mathrm{Li}-\mathrm{X}$ alloys for optimization. $\mathrm{Mg}$ and $\mathrm{Mn}$ were added into $\mathrm{Zn}-\mathrm{Li}$ alloy for the purpose of strengthening the matrix or improving the ductility, respectively. As shown in Fig. 8, as-extruded $\mathrm{Zn}-0.8 \mathrm{Li}-0.4 \mathrm{Mg}$ alloy reached a UTS of $646.69 \pm 12.79 \mathrm{MPa}(n=4)$, which is the highest tensile strength reported for $\mathrm{Zn}$ alloys according to latest review paper ${ }^{14}$. As for $\mathrm{Zn}-\mathrm{Li}-\mathrm{Mn}$ alloys, surprisingly high elongation was found after adding Mn compared with $\mathrm{Zn}-\mathrm{Li}$ alloys. $\mathrm{Zn}-0.8 \mathrm{Li}-0.8 \mathrm{Mn}$ alloy possessed an elongation to failure up to $103.27 \pm 20 \%(n=4)$ while maintaining a UTS of $514.43 \pm 19.36$ MPa $(n=4)$. The outstanding mechanical properties of $\mathrm{Zn}-\mathrm{Li}-\mathrm{Mg}$ and $\mathrm{Zn}-\mathrm{Li}-\mathrm{Mn}$ alloys are comparable to clinically used pure Ti and 316 stainless steel.

Figure 9 illustrates the mechanical properties and clinical applications of currently used materials for orthopedic devices. Cobalt chromium alloys, $316 \mathrm{~L}$ stainless steel, and titanium-based alloys are major non-degradable materials for load-bearing applications due to their high strength, superior corrosion resistance in body environment and excellent biocompatibility. Among them, titanium alloys are fast emerging as the first choice 


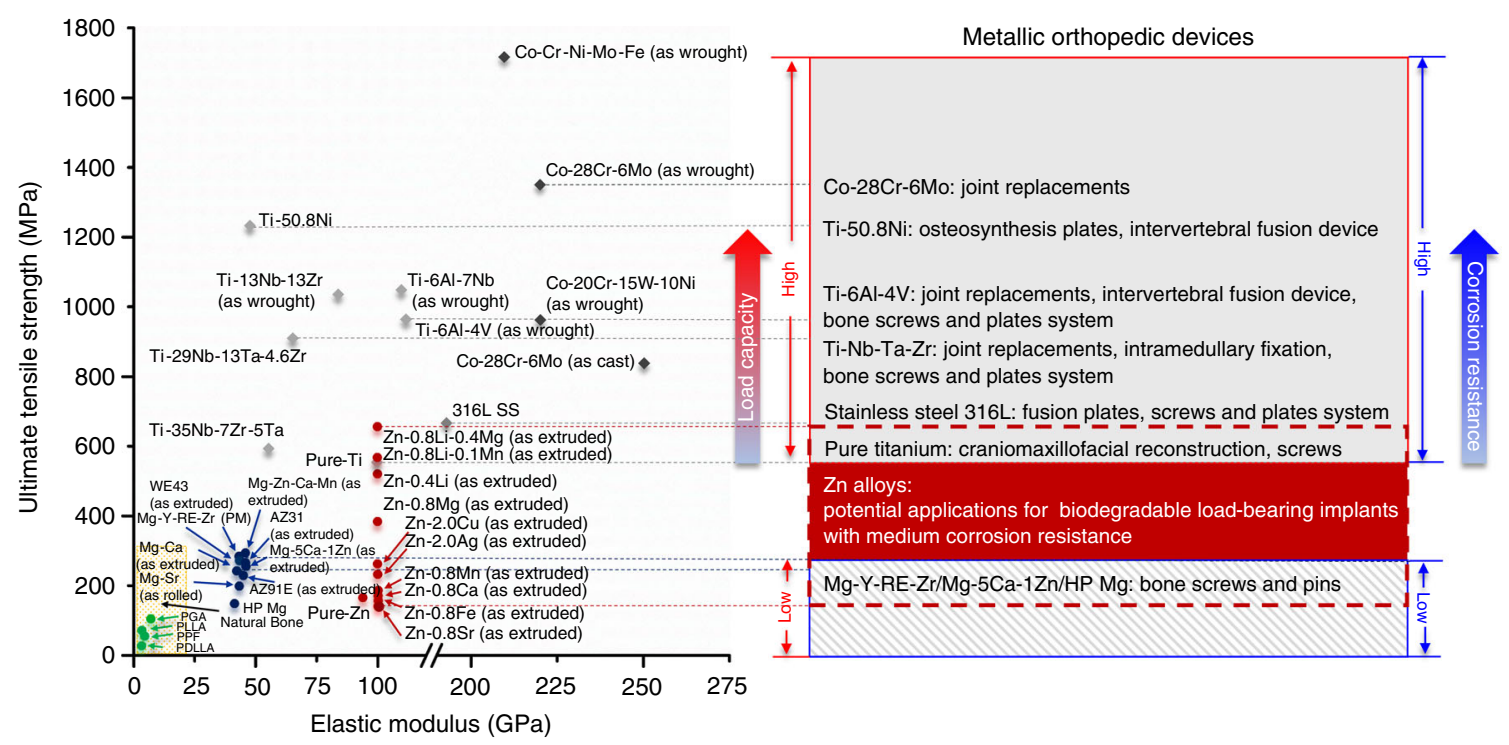

Fig. 9 Mechanical properties of biodegradable and non-biodegradable materials for orthopedic devices and their clinical applications. (Ti-based alloys, Co-Cr alloys and $316 \mathrm{~L}$ stainless steel ${ }^{7,8,56}$, biodegradable $\mathrm{Mg}$-based alloys $3,4,41,43,45,57$, biodegradable polymers ${ }^{1,58}$ ).

for the majority of applications due to its high immunity to corrosion, low modulus, and high capacity to join with bone. Commercial pure $\mathrm{Ti}$ and $\mathrm{Ti}-6 \mathrm{Al}-4 \mathrm{~V}$ are the most commonly used titanium materials, which cover joint replacements, intervertebral fusion devices, craniomaxillofacial reconstruction, and bone screw and plate systems, from high load-bearing to low loadbearing applications. To avoid stress shielding and secondary surgery, biodegradable materials including polymers and metals have been developed for orthopedic devices. Polyglycolide (PGA), polylactide (PLA), and poly (L-lactic acid) (PLLA) are FDA approved polymer products with similar mechanical properties to cancellous bone. However, they are only intended for applications like soft tissue graft fixation and meniscus repair due to their low strength. In contrast to polymers, Mg-based materials possess higher strength and modulus that are close to cortical bone. $\mathrm{Mg}$ based materials advanced rapidly in recent years with two material products (MgYReZr and MgZnCa alloys) approved by Conformité Européene (CE) and the Korea Food and Drug Administration (KFDA), respectively. They are fabricated into bone screws and pins indicated for intra-articular and extraarticular fractures of small bones and bone fragments. Therefore, both polymers and $\mathrm{Mg}$-based materials are incapable of high load-bearing applications as a result of their insufficient mechanical strength. In contrast, the mechanical strength of $\mathrm{Zn}$ alloys falls in a wide range, from the value of pure $\mathrm{Mg}$ to the value of commercial pure $\mathrm{Ti}$ and 316 stainless steel. The promising mechanical performance of $\mathrm{Zn}$ alloys can motivate scientists and clinicians to consider using biodegradable Zn-based implants in not only low load-bearing sites but also some of the high loadbearing sites and extend the clinical applications of biodegradable implants.

In summary, our work evaluated binary $\mathrm{Zn}$ alloys as biodegradable bone implants comprehensively by both in vitro and in vivo experiments with regard to mechanical property, biodegradability, and biocompatibility. Our findings have significant implications for understanding the degradation behavior and biological responses of $\mathrm{Zn}$-based alloys in bone environments. This study lays the groundwork for future research into the design strategy of biodegradable Zn-based alloys specifically as bone implants and directs their clinical prospects. Zn-based alloys have immense potential to play a pivotal role in biodegradable bone implants for load-bearing applications.

\section{Methods}

Material preparation. Pure $\mathrm{Zn}$ and $\mathrm{Zn}$ alloys were fabricated by Hunan rare earth metal material research institute. The analyzed chemical compositions of nominal binary and ternary $\mathrm{Zn}$ alloys were given in Supplementary Tables 1 and 2. For Mg, $\mathrm{Ca}, \mathrm{Sr}, \mathrm{Li}, \mathrm{Mn}$ and $\mathrm{Fe}, 0.1,0.4$, and $0.8 \mathrm{wt} \%$ of alloying elements were added due to their limited solubility in $\mathrm{Zn} .0 .4,0.8$, and $2.0 \mathrm{wt} \%$ of $\mathrm{Cu}$ and $\mathrm{Ag}$ were added based on their relatively high solubility in $\mathrm{Zn}$. The material ingots were homogenized at $350^{\circ} \mathrm{C}$ for $48 \mathrm{~h}$ followed by water quenching. Then, the ingots were hot extruded at $260^{\circ} \mathrm{C}$ with an extrusion ratio of $36: 1$. The as-extruded pure $\mathrm{Zn}$ and $\mathrm{Zn}$ alloys were cut into square samples $\left(10 \times 10 \times 1 \mathrm{~mm}^{3}\right)$ perpendicular to the extrusion direction for microstructure, corrosion and cytocompatibility tests. All samples were grounded to 2000 grit with $\mathrm{SiC}$, followed by ultrasonically cleaning in acetone, absolute ethanol and distilled water. Samples were sterilized by ultraviolet-radiation for at $4 \mathrm{~h}$ for each side before cell tests.

Microstructure characterization. Samples were further grounded to 7000 grit and polished by $0.1 \mu \mathrm{m}$ diamond paste, then cleaned in distill water. All samples were etched with a $4 \% \mathrm{HNO}_{3} /$ alcohol solution. A SEM (Hitachi S-4800, Japan) equipped with energy dispersive spectrometry (EDS) was utilized for microstructure observation and composition analysis. X-ray diffractometer (XRD, Rigaku DMAX 2400, Japan) using CuKa was operated at $40 \mathrm{kV}$ and $100 \mathrm{~mA}$ to identify the phase composition of samples with scanning range from $10^{\circ}$ to $90^{\circ}$ at a scan rate of $2^{\circ} \min ^{-1}$ and step of $0.02^{\circ}$.

Mechanical tests. Samples for tensile tests and compressive tests were machined along the extrusion direction according to ASTM-E8-04a and ASTM-E9-89 and carried out in a universal material test machine (Instron 5969, USA) at room temperature. For tensile and compressive tests, the displacement rates were $1 \times 10^{-4} \mathrm{~s}^{-1}$ and $2 \times 10^{-4} \mathrm{~s}^{-1}$, respectively. The yield strength was determined as the stress at which the $0.2 \%$ plastic deformation occurred. The maximum stress before $50 \%$ compressive strain was defined as ultimate compressive strength. Microhardness test was adopted by a microhardness tester (SHIMADZUHMV-2t) measuring Vickers hardness with $0.1 \mathrm{kN}$ loading force and $15 \mathrm{~s}$ dwell time. An average of at least five measurements was taken for each group.

Electrochemical tests. The electrochemical tests were conducted with an electrochemical working station (Autolab, Metrohm, Switzerland) at $37^{\circ} \mathrm{C}$ in SBF solution $\left(\mathrm{NaCl} 8.035 \mathrm{~g} \mathrm{~L}^{-1}, \mathrm{NaHCO}_{3} 0.355 \mathrm{~g} \mathrm{~L}^{-1}, \mathrm{KCl} 0.25 \mathrm{~g} \mathrm{~L}^{-1}, \mathrm{~K}_{2} \mathrm{HPO}_{4} \cdot 3 \mathrm{H}_{2} \mathrm{O} 0.231 \mathrm{~g} \mathrm{~L}^{-1}\right.$, $\mathrm{MgCl}_{2} \cdot 6 \mathrm{H}_{2} \mathrm{O} 0.311 \mathrm{~g} \mathrm{~L}^{-1}, \mathrm{HCl}(36-38 \%) 39 \mathrm{~mL} \mathrm{~L}^{-1}, \mathrm{CaCl}_{2} 0.292 \mathrm{~g} \mathrm{~L}^{-1}, \mathrm{Na}_{2} \mathrm{SO}_{4}$ $0.072 \mathrm{~g} \mathrm{~L}^{-1}$, Tris $6.118 \mathrm{~g} \mathrm{~L}^{-1}, \mathrm{pH} 7.4$ ). A three-electrode cell with counter electrode made of platinum and a saturated calomel electrode (SCE) as the reference electrode was used. The open-circuit potential (OCP) was monitored for $5400 \mathrm{~s}$ for each sample. Potentiodynamic polarization was carried out at a scan rate of $1 \mathrm{mV} \mathrm{s}^{-1}$ ranging from -500 to $500 \mathrm{mV}$ (vs. OCP), and with a test area of $0.2826 \mathrm{~cm}^{2}$. Corrosion potential $\left(E_{\text {corr }}\right)$ and corrosion current density $\left(i_{\text {corr }}\right)$ were calculated by linear fit and Tafel extrapolation. An average of at least five measurements was taken for each group.

Immersion tests. Samples were immersed in SBF solutions at $37^{\circ} \mathrm{C}$ for 30 days with a solution to area ratio of $20 \mathrm{~mL} \mathrm{~cm}^{-2}$ according to ASTM-G31-72. The $\mathrm{pH}$ 
value was monitored by a pH meter (Mettler Five Easy pH FE20K) and the solution was refreshed every $48 \mathrm{~h}$. After immersion, samples were rinsed by distill water and dried in air. The corrosion morphology before and after removal of corrosion products was observed by SEM. A solution containing $200 \mathrm{~g} \mathrm{~L}^{-1} \mathrm{CrO}_{3}$ was used for cleaning the corrosion products. The corrosion rates of samples were calculated based on the weight loss according to the equation: $C=\Delta m \rho^{-1} A^{-1} \mathrm{t}^{-1}$, where $C$ is the corrosion rate in mm year ${ }^{-1}, \Delta m$ is the weight loss, $\rho$ is the density of the material, $A$ is the initial implant surface area, and $t$ is the implantation time. An average of at least five measurements was taken for each group.

Cytocompatibility. Osteoblast precursor cell line (MC3T3-E1, ATCC CRL-2594") and human umbilical vein endothelial cells (HUVECs, ATCC CRL-1730" ${ }^{\mathrm{m}}$ ) were adopted to evaluate the cytotoxicity of pure Zn and binary $\mathrm{Zn}$ alloys. MC3T3-E1 and HUVEC cells were cultured in alpha-minimum essential medium (MEM) and Dulbecco's modified Eagle's medium (DMEM) with 10\% fetal bovine serum (FBS), $100 \mathrm{U} \mathrm{mL}^{-1}$ penicillin and $100 \mu \mathrm{g} \mathrm{mL} \mathrm{L}^{-1}$ streptomycin at $37^{\circ} \mathrm{C}$ in a humidified atmosphere of $5 \% \mathrm{CO}_{2}$. Extracts were prepared by using culture medium with a surface area to medium ratio of $1.25 \mathrm{~mL} \mathrm{~cm}^{-2}$ at $37^{\circ} \mathrm{C}$ in a humidified atmosphere of $5 \% \mathrm{CO}_{2}$ for $24 \mathrm{~h}$. The supernatant fluid was withdrawn, centrifuged and kept at $4{ }^{\circ} \mathrm{C}$ prior to use. Cells were incubated in 96-well plates at a density of $3 \times 10^{4}$ cells $\mathrm{mL}^{-1}$ in each well for $24 \mathrm{~h}$ to allow attachment. The culture medium was then replaced by $100 \mu \mathrm{L} 100$ and $50 \%$ sample extracts. The culture medium was used as negative control and culture medium with $10 \%$ dimethyl sulfoxide (DMSO, Invitrogen, USA) as positive control. After 1,2, and 4 days' incubation, the extracts were replaced by fresh culture medium, $10 \mu \mathrm{L}$ Cell Counting Kit-8 (CCK-8, Dojindo, Kumamoto, Japan) was added into each well and incubated at $37^{\circ} \mathrm{C}$ in a humidified atmosphere of $5 \% \mathrm{CO}_{2}$ for $1 \mathrm{~h}$. The spectrophotometrical absorbance of mediums were measured at $450 \mathrm{~nm}$ using a microplate reader (Bio-RAD680). An average of at least five measurements was taken for each group. For cytoskeleton and cell spreading, sterilized samples were put in 24-well plates. Five hundred microliter cell suspension were added into the samples at a density of $8 \times 10^{4}$ cells mL $\mathrm{m}^{-1}$ and incubated for $12 \mathrm{~h}$. cells were then washed with PBS, fixed using $4 \%\left(\mathrm{w} \mathrm{v}^{-1}\right)$ paraformaldehyde for $10 \mathrm{~min}$ and permeabilized with $0.1 \%\left(\mathrm{v} \mathrm{v}^{-1}\right)$ Triton X-100 (Sigma) for $7 \mathrm{~min}$. Afterwards, $1 \mathrm{mg} \mathrm{mL} \mathrm{mL}^{-1}$ DAPI (Sigma) and $1.0 \%\left(\mathrm{v} \mathrm{v}^{-1}\right)$ FITC-phalloidin (Sigma) were used to stain the nuclei and cellular actin for $5 \mathrm{~min}$ and $30 \mathrm{~min}$, respectively. Cells were washed by PBS to remove the residue dye and viewed under an inverted confocal laser scanning microscope (CLSM, Leica TCS SP5, Germany).

Surgical procedure. Implants of pure $\mathrm{Zn}$ and binary $\mathrm{Zn}$ alloys $(\Phi 1.6 \times 15 \mathrm{~mm})$ were machined from the as-extruded samples. A rat femur model was used and the surgical procedures were conducted under sterile conditions. Intraperitoneal injection of ketamine $\left(10 \mathrm{mg} \mathrm{kg}^{-1}\right)$ and $2 \%$ xylazine $\left(5 \mathrm{mg} \mathrm{kg}^{-1}\right)$ were used to anesthetize the rats. Each rat was immobilized with the knee joint in maximally flexed position and the right hind limb was shaved and depilated. A $15 \mathrm{~mm}$ long incision was made longitudinally along the lateral side of the humerus to dislocate the knee joint. With the knee in flexion, a cylindrical hole $(1.6 \mathrm{~mm}$ in diameter was drilled in the center of the femoral condyle parallel to the long axis of the femur. After the bone cavity was washed with normal saline, a metal implant was inserted into the right femur, and, subsequently, the wound was closed carefully. Each rat received only one implant. At least six implants of each alloy type were tested. At least fifty-four male Sprague Dawley rats aged 3 months and weighed by an average of $200 \mathrm{~g}$ were randomized to either group. After surgery, the rats were housed in ventilated rooms and given access to water and food. At 8 weeks, the rats were sacrificed and the right femurs were explanted and fixed in 10\% neutral formalin buffer for Micro-CT and histological analysis. X-ray scan was performed post surgically and at 8 weeks. The $\mathrm{Zn}$ ion concentrations in blood serum were measured by inductively coupled Plasma optical emission spectroscope (ICP-OES, iCAP6300, Thermo). All the animal procedures have complied with relevant ethical regulations for animal research and were approved by the Animal Ethical Committee at the Ninth People's Hospital affiliated to Shanghai Jiaotong University, School of Medicine (Shanghai, China).

Micro-CT analysis. A Skyscan 1172 Micro-CT system (Bruker Micro-CT N.V., Kontich, Belgium) was adopted to analyze the implants. Explanted rat femurs were examined with a $20 \mu \mathrm{m}$ resolution protocol $\left(100 \mathrm{kV}, \mathrm{Al}+\mathrm{Cu}\right.$ filter, $0.6^{\circ}$ rotation step, frame averaging of $2^{\circ}, 360^{\circ}$ rotation). The CT images were reconstructed by using Skyscan NRecon software and further analyzed by CTAn, CTVol, and CTVox software to produce 3D images and volume loss data. The degradation rate, $\mathrm{DR}$, was calculated based on the equation:

$$
\mathrm{DR}=\frac{V_{0}-V_{\mathrm{t}}}{\mathrm{At}},
$$

where $V_{0}$ is the volume of the implant before implantation, $V_{\mathrm{t}}$ is the volume of the implant at the designated implantation time interval. $t$ is the implantation time and $A$ is the initial implant surface area.

Cross sectional analysis. Hard tissue blocks were cut to produce sections of $1 \mathrm{~mm}$ thickness. Cross section samples were prepared by grinding with 7000 grit $\mathrm{SiC}$ paper and polished with $0.1 \mu \mathrm{m}$ diamond paste. Cross sections in the femoral condyle were used for examination. At least five sections were produced in each group. The polished samples were coated with a thin layer of gold before analyzing by SEM equipped with EDS.

Histological preparation and histomorphometric analysis. After fixation, the implants were rinsed in water, dehydrated in ethanol, cleared in xylene and embedded in methyl methacrylate. The histological sections were generated perpendicular to the long axis of the implants around the femoral condyle. At least six sections were produced in each group for analysis. Sections were grinded to $100 \mu \mathrm{m}$ thickness, polished and stained with van Gieson's Picrofuschin. The specimens were observed under a high-quality microscope (Olympus CKX41, Japan). To quantify bone-to-implant contact (BIC) and bone area (BA), the osseointegrated implant surface and bone area within a ring of $100 \mu \mathrm{m}$ around the implant were assessed. The BIC represents the available implant perimeter in contact with bone normalized over the implant perimeter length. BA was defined as a ratio of bone area to total area extending $100 \mu \mathrm{m}$ from the implant.

Statistical analysis. The data were evaluated by one-way analysis of variance (ANOVA) followed by post hoc Tukey's multiple comparison test. The data were presented as mean \pm standard deviation $(n \geq 3$, independent samples) and a difference of ${ }^{\star} P<0.05$ was considered significant.

Reporting summary. Further information on research design is available in the Nature Research Reporting Summary linked to this article.

\section{Data availability}

The source data underlying Figs. 1b, c, 2a-c, 3b, c, 4a, 5b, c, 6c, 7b-d, 8a, b and Supplementary Figs. 1, $3 \mathrm{a}-\mathrm{c}$ and Supplementary Table 3 are provided as a Source Data file. Additional data related to this paper may be requested from the authors.

Received: 11 July 2019; Accepted: 6 December 2019; Published online: 21 January 2020

\section{References}

1. Sabir, M. I., Xu, X. \& Li, L. A review on biodegradable polymeric materials for bone tissue engineering applications. J. Mater. Sci. 44, 5713-5724 (2009).

2. Middleton, C. \& Tipton, A. J. Synthetic biodegradable polymers as orthopedic devices. Biomaterials 21, 2335-2346 (2000).

3. Henning, W. et al. Biodegradable magnesium-based screw clinically equivalent to titanium screw in hallux valgus surgery: short term results of the first prospective, randomized, controlled clinical pilot study. Biomed. Eng. Online 12, 62-62 (2013).

4. Lee, J. W. et al. Long-term clinical study and multiscale analysis of in vivo biodegradation mechanism of Mg alloy. Proc. Natl Acad. Sci. USA 113, 716-721 (2016)

5. Zhao, D. et al. Vascularized bone grafting fixed by biodegradable magnesium screw for treating osteonecrosis of the femoral head. Biomaterials 81, 84-92 (2016)

6. Zheng, Y. F., Gu, X. N. \& Witte, F. Biodegradable metals. Mater. Sci. Eng. R 77, 1-34 (2014)

7. Zivic, F. et al. Biomaterials in Clinical Practice: Advances in Clinical Research and Medical Devices (Springer, 2017).

8. Geetha, M., Singh, A. K., Asokamani, R. \& Gogia, A. K. Ti based biomaterials, the ultimate choice for orthopaedic implants-a review. Prog. Mater. Sci. 54, 397-425 (2009).

9. Vojtěch, D., Kubásek, J., Šerák, J. \& Novák, P. Mechanical and corrosion properties of newly developed biodegradable $\mathrm{Zn}$-based alloys for bone fixation. Acta Biomater. 7, 3515-3522 (2011).

10. Jin, $\mathrm{H}$. et al. Novel high-strength, low-alloys $\mathrm{Zn}-\mathrm{Mg}(<0.1 \mathrm{wt} \% \mathrm{Mg})$ and their arterial biodegradation. Mater. Sci. Eng. C 84, 67-79 (2018).

11. Zhao, S. et al. Structural characteristics and in vitro biodegradation of a novel zn-li alloy prepared by induction melting and hot rolling. Metall. Mater. Trans. A 48, 1204-1215 (2017).

12. Seo, H. J., Cho, Y. E., Kim, T., Shin, H. I. \& Kwun, I. S. Zinc may increase bone formation through stimulating cell proliferation, alkaline phosphatase activity and collagen synthesis in osteoblastic MC3T3-E1 cells. Nutr. Res. Pract. 4, 356-361 (2010).

13. Moonga, B. S. \& Dempster, D. W. Zinc is a potent inhibitor of osteoclastic bone resorption in vitro. J. Bone Miner Res. 10, 453-457 (2010).

14. Venezuela, J. \& Dargusch, M. The influence of alloying and fabrication techniques on the mechanical properties, biodegradability and 
biocompatibility of zinc: a comprehensive review. Acta Biomater. 87, 1-40 (2019).

15. Mostaed, E., Sikora-Jasinska, M., Drelich, J. W. \& Vedani, M. Zinc-based alloys for degradable vascular stent applications. Acta Biomater. 71, 1-23 (2018).

16. Li, H. F. et al. Development of biodegradable $\mathrm{Zn}-1 \mathrm{X}$ binary alloys with nutrient alloying elements $\mathrm{Mg}$, Ca and Sr. Sci. Rep. 5, 10719 (2015).

17. Xiao, C. et al. Indirectly extruded biodegradable $\mathrm{Zn}-0.05 \mathrm{wt} \% \mathrm{Mg}$ alloy with improved strength and ductility: In vitro and in vivo studies. J. Mater. Sci. Technol. 34, 1618-1627 (2018).

18. Murni, N., Dambatta, M., Yeap, S., Froemming, G. R. A. \& Hermawan, H. Cytotoxicity evaluation of biodegradable $\mathrm{Zn}-3 \mathrm{Mg}$ alloy toward normal human osteoblast cells. Mater. Sci. Eng. C 49, 560-566 (2015).

19. Yang, H. et al. Enhanced osseointegration of $\mathrm{Zn}-\mathrm{Mg}$ composites by tuning the release of $\mathrm{Zn}$ ions with sacrificial $\mathrm{Mg}$-rich anode design. ACS Biomater. Sci. Eng. 5, 453-467 (2018).

20. Sanchez, A. H. M., Luthringer, B. J. C., Feyerabend, F. \& Willumeit, R. Mg and Mg alloys: How comparable are in vitro and in vivo corrosion rates? A review. Acta Biomater. 13, 16-31 (2015).

21. Zhang, Y. et al. Implant-derived magnesium induces local neuronal production of CGRP to improve bone-fracture healing in rats. Nat. Med. 22, 1160-1169 (2016).

22. Heaney, R. P. Calcium, dairy products and osteoporosis. J. Am. Coll. Nutr. 19, 83-99 (2000).

23. Buehler, J., Chappuis, P., Saffar, J., Tsouderos, Y. \& Vignery, A. Strontium ranelate inhibits bone resorption while maintaining bone formation in alveolar bone in monkeys (Macaca fascicularis). Bone 29, 176-179 (2001).

24. Baron, R. \& Tsouderos, Y. In vitro effects of S12911-2 on osteoclast function and bone marrow macrophage differentiation. Eur. J. Pharmacol. 450, 11-17 (2002).

25. Clément-Lacroix, P. et al. Lrp5-independent activation of Wnt signaling by lithium chloride increases bone formation and bone mass in mice. Proc. Natl Acad. Sci. 102, 17406-17411 (2005).

26. Zamani, A., Omrani, G. R. \& Nasab, M. M. Lithium's effect on bone mineral density. Bone 44, 331-334 (2009).

27. Aschner, J. L. \& Aschner, M. Nutritional aspects of manganese homeostasis. Mol. Asp. Med. 26, 353-362 (2005).

28. Katsumata, S., Katsumata-Tsuboi, R., Uehara, M. \& Suzuki, K. Severe iron deficiency decreases both bone formation and bone resorption in rats. J. Nutr. 139, 238-243 (2008).

29. Harris, M. M. et al. Dietary iron is associated with bone mineral density in healthy postmenopausal women. J. Nutr. 133, 3598-3602 (2003).

30. Aaseth, J., Boivin, G. \& Andersen, O. Osteoporosis and trace elements-an overview. J. Trace Elem. Med. Biol. 26, 149-152 (2012).

31. Beattie, J. H. \& Avenell, A. Trace element nutrition and bone metabolism. Nutr. Res. Rev. 5, 167-188 (1992).

32. Zhang, R. et al. Silver nanoparticles promote osteogenesis of mesenchymal stem cells and improve bone fracture healing in osteogenesis mechanism mouse model. Nanomedicine 11, 1949-1959 (2015).

33. Staiger, M. P., Pietak, A. M., Huadmai, J. \& Dias, G. Magnesium and its alloys as orthopedic biomaterials: a review. Biomaterials 27, 1728-1734 (2006).

34. Kraus, T. et al. Magnesium alloys for temporary implants in osteosynthesis: in vivo studies of their degradation and interaction with bone. Acta Biomater. 8, 1230-1238 (2012).

35. Thomas, S., Birbilis, N., Venkatraman, M. S. \& Cole, I. S. Corrosion of zinc as a function of pH. Circ. Res. 68, 160-166 (2012).

36. Kraus, T. et al. Biodegradable Fe-based alloys for use in osteosynthesis: Outcome of an in vivo study after 52weeks. Acta Biomater. 10, 3346-3353 (2014).

37. Yang, H. et al. Evolution of the degradation mechanism of pure zinc stent in the one-year study of rabbit abdominal aorta model. Biomaterials 145, 92-105 (2017).

38. Niu, J. et al. The in vivo degradation and bone-implant interface of Mg-Nd$\mathrm{Zn}-\mathrm{Zr}$ alloy screws: 18 months post-operation results. Corros. Sci. 113, 183-187 (2016).

39. Jun, M. A., Nan, Z. \& Zhu, D. Endothelial cellular responses to biodegradable metal zinc. ACS Biomater. Sci. Eng. 1, 1174-1182 (2015).

40. Ma, J., Zhao, N. \& Zhu, D. Bioabsorbable zinc ion induced biphasic cellular responses in vascular smooth muscle cells. Sci. Rep. 6, 26661 (2016).

41. Han, H. S. et al. Current status and outlook on the clinical translation of biodegradable metals. Mater. Today 23, 57-71 (2019).

42. Wang, J. et al. Magnesium (Mg) based interference screws developed for promoting tendon graft incorporation in bone tunnel in rabbits. Acta Biomater. 63, 393-410 (2017).

43. Han, P. et al. In vitro and in vivo studies on the degradation of high-purity $\mathrm{Mg}$ (99.99 wt.\%) screw with femoral intracondylar fractured rabbit model. Biomaterials 64, 57-69 (2015).
44. Henderson, S. E. et al. Magnesium alloys as a biomaterial for degradable craniofacial screws. Acta Biomater. 10, 2323-2332 (2014).

45. Gu, X., Xie, X., Li, N., Zheng, Y. \& Qin, L. In vitro and in vivo studies on a $\mathrm{Mg}-\mathrm{Sr}$ binary alloy system developed as a new kind of biodegradable metal. Acta Biomater. 8, 2360-2374 (2012).

46. Zhang, S. et al. Research on an Mg-Zn alloy as a degradable biomaterial. Acta Biomater. 6, 626-640 (2010).

47. Dai, Y. et al. Mechanical strengthening mechanism of $\mathrm{Zn}-\mathrm{Li}$ alloy and its mini tube as potential absorbable stent material. Mater. Lett. 235, 220-223 (2019).

48. Zhang, Y. et al. Investigation on the microstructure, mechanical properties, in vitro degradation behavior and biocompatibility of newly developed $\mathrm{Zn}$ 0.8\% Li-(Mg, Ag) alloys for guided bone regeneration. Mater. Sci. Eng. C 99 1021-1034 (2019)

49. Sun, S. et al. Abnormal effect of Mn addition on the mechanical properties of as-extruded Zn alloys. Mater. Sci. Eng. A 701, 129-133 (2017)

50. Kafri, A., Ovadia, S., Goldman, J., Drelich, J. \& Aghion, E. The suitability of $\mathrm{Zn}-1.3 \%$ Fe alloy as a biodegradable implant material. Metals 8, 153-167 (2018).

51. Brennan, T. C. et al. Osteoblasts play key roles in the mechanisms of action of strontium ranelate. Br. J. Pharmacol. 157, 1291-1300 (2009)

52. Tipton, I. H. \& Cook, M. Trace elements in human tissue. Health Phys. 9, 103 (1963).

53. Liu, Y. et al. Fundamental theory of biodegradable metals-definition, criteria, and design. Adv. Funct. Mater. 29, 1805402 (2019).

54. Dermience, M., Lognay, G., Mathieu, F. \& Goyens, P. Effects of thirty elements on bone metabolism. J. Trace Elem. Med. Biol. 32, 86-106 (2015).

55. Yamamoto, A., Honma, R. \& Sumita, M. Cytotoxicity evaluation of 43 metal salts using murine fibroblasts and osteoblastic cells. J. Biomed. Mater. Res. 39, 331-340 (1998)

56. Elahinia, M. H., Hashemi, M., Tabesh, M. \& Bhaduri, S. B. Manufacturing and processing of NiTi implants: a review. Prog. Mater. Sci. 57, 911-946 (2012).

57. Zhang, X., Yuan, G., Mao, L., Niu, J. \& Ding, W. Biocorrosion properties of asextruded $\mathrm{Mg}-\mathrm{Nd}-\mathrm{Zn}-\mathrm{Zr}$ alloy compared with commercial AZ31 and WE43 alloys. Mater. Lett. 66, 209-211 (2012).

58. Onuma, Y. \& Serruys, P. W. Bioresorbable Scaffolds: From Basic Concept to Clinical Applications (CRC Press, 2017).

59. Gunde, P., Hänzi, A., Sologubenko, A. \& Uggowitzer, P. J. High-strength magnesium alloys for degradable implant applications. Mater. Sci. Eng A 528, 1047-1054 (2011)

60. Wan, Y. et al. Preparation and characterization of a new biomedical magnesium-calcium alloy. Mater. Des. 29, 2034-2037 (2008).

61. Mostaed, E. et al. Microstructure, texture evolution, mechanical properties and corrosion behavior of ECAP processed ZK60 magnesium alloy for biodegradable applications. J. Mech. Behav. Biomed. Mater. 37, 307-322 (2014).

62. Smithells, C. J. Smithells Metals Reference Book. (Elsevier, Boston, 2004).

63. Seitz, J. M., Durisin, M., Goldman, J. \& Drelich, J. W. Recent advances in biodegradable metals for medical sutures: a critical review. Adv. Healthc. Mater. 4, 1915-1936 (2015)

64. Dean, J. A. Lange's Handbook of Chemistry. (McGraw-Hill, New York, 1999).

65. Stanners, C., Eliceiri, G. \& Green, H. Two types of ribosome in mouse-hamster hybrid cells. Nat. New Biol. 230, 52-54 (1971).

66. Zhao, N. \& Zhu, D. Endothelial responses of magnesium and other alloying elements in magnesium-based stent materials. Metallomics 7, 118-128 (2015).

\section{Acknowledgements}

This work was supported by the National Key R\&D Program of China (2018YFE0104200), the National Natural Science Foundation of China (Grant No 51931001), the NSFC/RGC Joint Research Scheme (Grant No. 5161101031), the Peking University Medicine Seed Fund for Interdisciplinary Research (Grant No. BMU2018ME005

\section{Author contributions}

H.Y., B.J., Y.Z., and K.D. designed the concept of the experiments. H.Y., Z.Z., and G.L. fabricated the materials and conducted the material characterizations, corrosion tests and cytotoxicity. B.J. and X.Q. conducted the implantation and histology analysis. W.L. provided important assistant in Micro-CT study. H.Y. and Y.Z. analyzed the experimental data and wrote the manuscript. D.Z. provided important experimental insights. All the authors have given approval to the final version of the manuscript.

\section{Competing interests}

The authors declare no competing interests. 


\section{Additional information}

Supplementary information is available for this paper at https://doi.org/10.1038/s41467019-14153-7.

Correspondence and requests for materials should be addressed to K.D. or Y.Z.

Peer review information Nature Communications thanks Jack Zhou, Jeffrey Jones and Hamdy Ibrahim for their contribution to the peer review of this work.

Reprints and permission information is available at http://www.nature.com/reprints

Publisher's note Springer Nature remains neutral with regard to jurisdictional claims in published maps and institutional affiliations. (c) (i) Open Access This article is licensed under a Creative Commons Attribution 4.0 International License, which permits use, sharing, adaptation, distribution and reproduction in any medium or format, as long as you give appropriate credit to the original author(s) and the source, provide a link to the Creative Commons license, and indicate if changes were made. The images or other third party material in this article are included in the article's Creative Commons license, unless indicated otherwise in a credit line to the material. If material is not included in the article's Creative Commons license and your intended use is not permitted by statutory regulation or exceeds the permitted use, you will need to obtain permission directly from the copyright holder. To view a copy of this license, visit http://creativecommons.org/licenses/by/4.0/.

(C) The Author(s) 2020 